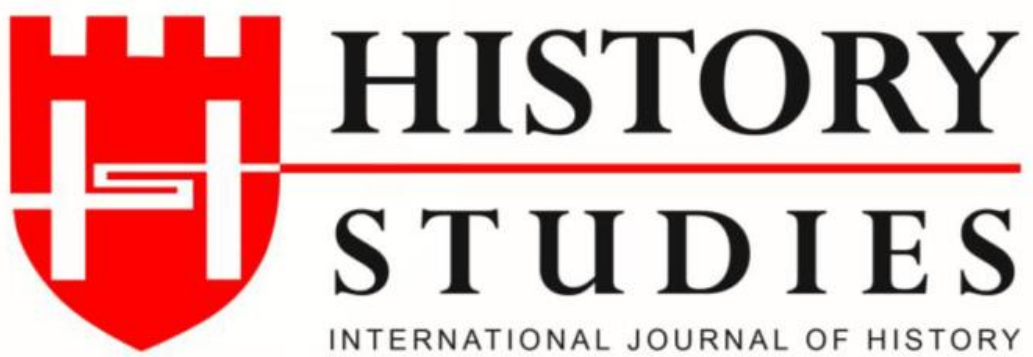

ISSN: 13094173 (Online) 1309 - 4688 (Print)

Volume 12 Issue 2, A Tribute to Assoc. Prof. Dr. İlknur Mangır Karagöz, April 2020

DOI Number: 10.9737/hist.2020.846

Araştırma Makalesi

Makalenin Geliş Tarihi: 04.03.2020 Kabul Tarihi: 25.03.2020

Atıf Künyesi: Abdullah Saydam, “Tanzimat Döneminde Yolsuzlukla Suçlanan Bir Vali: Mehmed

Vecîhî Paşa", History Studies, Doç. Dr. İlknur Mangır Karagöz Armağanı, 12/2, Nisan 2020, s. 595-618.

\title{
Tanzimat Döneminde Yolsuzlukla Suçlanan Bir Vali: Mehmed Vecîhî Paşa
}

\author{
A Governor Accused of Corruption in the Tanzimat Period: \\ Mehmed Vecihi Pasha
}

\author{
Prof. Dr. Abdullah Saydam \\ ORCID No: 0000-0003-0882-5421 \\ Erciyes Üniversitesi
}

Volume 12

Issue 2

A Tribute to

Assoc. Prof.

Dr. İlknur

Mangir

Karagöz,

April

2020

Öz: Mehmed Vecîhî Paşa, 1828-1867 yılları arasında üst düzey yöneticiliklerde bulunmuş, Osmanlı Devleti'nin son yüzyılının önemli bürokratlarından biridir. Rumeli ve Anadolu tarafındaki önemli vilayetlerde görev yaptı. Bosna'dan Selanik'e, Bağdat'tan Ankara'ya kadar Osmanlı coğrafyasının hemen her yerinde çalıştı. Tanzimat reformlarının taşrada uygulanmasında görev aldı. Merkezî bürokraside görev aldığ 1 dönemler de oldu. Ancak bunlar daha kısa süreli olmuștur. Bu görevleri sırasında zaman zaman suç ișlemekle itham edildi. Suçlamalar genellikle rüşvet alma, haksız kazanç elde etme, mal el koyma, görevi kötüye kullanma gibi hususları içermekteydi. Özellikle Halep, Ankara ve Erzurum valilikleri sırasındaki suçlamaların oldukça ciddi olduğu söylenebilir. Böyle ithamları duyduğunda görevden ayrılmak istediğini söylemekten kaçınmadı. Hükümet de kendisini aklamasına firsat vermeyi tercih etti. Bundan dolayı azledildi ve yargilandı. Uzun incelemeler sonucunda kendisine atılan hiçbir suçlamadan dolayı ceza almadı. Kanunlara aykırı işlem yapmadı̆̆ iftira atıldığı yolunda kararlar alındı. Bu çalışmada Vecîhî Paşa'ya yönelik suçlamalar, onun savunması, muhakeme süreci ve verilen kararlar ele alınmaktadır. Osmanlı arşiv belgeleri ile birinci el kaynaklar ve konuyla ilgili araştırmalardan yararlanılmıştır.

Anahtar kelimeler: Mehmed Vecîhî Paşa, Tanzimat dönemi, Ankara, Erzurum, Halep

Abstract: Mehmed Vecîhî Pasha, who was a senior executive from 1828 to 1867, was one of the most important bureaucrats of the Ottoman Empire in the last century. He worked in important provinces of Rumelia and Anatolia. From Bosnia to Thessaloniki, Baghdad to Ankara, he served in almost every part of the Ottoman geography. He took part in the implementation of Tanzimat reforms in the provinces. There were also periods when he worked in the central bureaucracy. However, these have been shorter. During these missions he was occasionally accused of committing the crime. The accusations generally included bribery, unfair profits, seizure of property, abuse of office. It can be said that the accusations made during the governorships of Aleppo, Ankara and Erzurum were quite serious. When he heard such charges, he did not hesitate to say he wanted to resign. The government chose to give him the opportunity to be right, too. He was therefore dismissed and tried. As a result of long investigations, he was not sentenced for any charges against him. Decisions were taken that he did not act against the law and that he was subjected to slander. In this study, it was examined accusations against Mehmed Vecihi Pasha, his defence, court process, decisions made. Ottoman archival documents, first hand sources and related researches were used in the research.

Keywords: Mehmed Vecihi Pasha, Tanzimat period, Ankara, Erzurum, Aleppo 


\section{Giriş}

Mehmed Vecîhî Paşa, 1828-1867 yılları arasında üst düzey yöneticiliklerde bulunmuş, Osmanlı Devleti'nin son yüzyılının önemli bürokratlarından biridir. Sultan II. Mahmud ile oğulları Abdülmecid ve Abdülaziz'in padişahlıkları döneminde Rumeli ve Anadolu tarafındaki en önemli vilayetlerde görev yaptığı gibi İstanbul'da da önemli birtakım kurumlarda vezir rütbesi ile çalıştı. Defalarca iftihar nişanları verildi. II. Mahmud döneminin reformları ile bunu izleyen Tanzimat yeniliklerinin taşrada uygulanması sürecinde görev yaptı. 1828 yılında Çirmen ve Edirne Kaimmakamı olarak başladığı mülkiye görevini Şeyhü'l-Harem, Hicaz ve Habeş Valisi olduğu sırada, 1867 yılında vefat etmesiyle tamamlamış oldu. ${ }^{1}$

Vecîhî Paşa kısa süreli mazûliyet zamanları olsa da neredeyse kırık yıla yaklaşan idarecilikleri süresince hem yönetimi altındaki halk nezdinde hem de Bâbıâli nezdinde genelde olumlu izlenimler bırakan biri yönetici idi. Nitekim Edirne'deki kaimmakamlık görevi sona erdiğinde göreve devam etmesi için halkın bazı girişimlerde bulunduğu görülmektedir. ${ }^{2}$ Yine Samakovcuk Nâzırlığı ve Varna Muhafızlığı görevi sırasında, 1828-1829 Savaşı sırasındaki işgallerden dolayı dağılan halkın yeniden yurtlarına yerleştirilmesi, Rusların Osmanlı topraklarını tahliye ederken buradaki gayrimüslim halk1 beraberlerinde götürmek için giriştikleri propagandaları ${ }^{3}$ etkisiz hale getirmek için gösterdiği gayretler reâyâ nezdinde son derece olumlu karşılanmış, yurtlarında kalmalarında bu girişimler etkili olmuştu. ${ }^{4}$

Bu kadar uzun süreli idarî görev dolayısıyla Vecîhî Paşa hakkında çok önemli suçlamalar ve şikâyetler de olmuştur. Nitekim Çirmen ve Edirne Kaimmakamlığ 1 sırasında amiri durumundaki Balkanlar Seraskeri Abdurrahim Paşa tarafindan cepheye asker ve mühimmat sevki ile ilgili görevlerini ihmal ettiği, Samakovcuk Nâzırlığı ve Varna Muhafızlığı sırasında da Silistre Valisi Mehmed Paşa ve onun etkisiyle Çirmen Mutasarrıfı Ağa Hüseyin Paşa tarafından reâyâ ile ilgili iş ve işlemlerde yetkisini aşarak kanuna ve usule aykırı davrandığı suçlamalarıyla Sadâret'e şikâyet edilmişti. Birinci suçlama İstanbul'da çok ciddiye alınmamış, ikinci suçlamada Sadrazam görevden alınmasını ve rütbesinin düşürülmesini teklif etmiş ise de, Sultan II. Mahmud azlini uygun bulmuş olmakla birlikte tenzil-i rütbe önerisini kabul etmemiştir. Zaten yaklaşık dört ay sonra Selanik ve Kavala Mutasarrıflığı'na tayin edilmiştir. ${ }^{5}$

Vecîhî Paşa hakkında yapılan şikâyetlerden bazılarının son derece ciddî bulunarak yargılanması yoluna gidildiği görülmektedir. Bu şekilde üç muhakeme olayı, birkaç defa da daha küçük kapsamlı şikâyetler söz konusu olmuştur. Bosna Valiliği sırasında yapıldığı iddia edilen haksız yere fazla vergi alma, suçsuz yere insanları sürgün veya hapis cezasına çarptırma gibi suçlarla ilgili olarak Paşa ve adamları itham edilmiş, kendisi özellikle bu duruma göz yummak ve gerekli tedbirleri almamakla suçlanmıştır. Yapılan yargılama sonucunda beraat

\footnotetext{
${ }^{1}$ Hayatı ve yaptığı görevler hakkında kısa bilgi için bkz. İsmail Sadık Kemal bin Muhammed Vecîhî Paşa, Asâr-ı Kemâl, İstanbul 1867, ek sayfalar. Vecîhî Paşa'nın büyük oğlu olan Kemal Paşa yazdığı eserin sonuna babasının ve annesinin dört sayfalık tercüme-i hâlini eklemiştir. Ayrıca şu eserlere de bakılabilir: Ahmed Bâdî Efendi, Riyâz-l Belde-i Edirne,20. Yüzylla Kadar Osmanlı Edirne'si, Haz. Niyazi Adigüzel ve Raşit Gündoğdu, C.II/1, Trakya Üniversitesi Yayınları, İstanbul 2014, s.1047-1048; Mehmed Süreyya, Sicill-i Osmanî, Haz. Nuri Akbayar, C.V, Tarih Vakfi Yurt Yayınları, İstanbul 1996, s.1655.

${ }^{2}$ BOA, HH, 306/18057, 1042/43108, 308/18229, 1042/43110, 1052/43307.

${ }^{3}$ Bkz. Ufuk Gülsoy, 1828-1829 Osmanlı - Rus Savaşı'nda Rumeli'den Rusya'ya Götürülen Reâyâ, Türk Kültürünü Araştırma Enstitüsü Yayınları, İstanbul 1993.

${ }^{4}$ Abdullah Saydam, "1828-1829 Türk - Rus Savaşı ve Bir Bürokratın Doğuşu: Mehmed Vecîhî Paşa”, History Studies, C.XI, S.4, s.1341-1361.

${ }^{5}$ BOA, HH, 660/32233; C.AS, 1210/54228, C.DH, 219/10902.
}

to


etmiştir ki, Tanzimat'ın ilanının hemen öncesinden yaşanan bu mesele kapsamlı bir araştırmaya konu olmuştur. ${ }^{6}$

Bu çalışmada Vecîhî Paşa'nın Tanzimat Fermanı'nın ilanından sonra yaptı̆ğ görevlerle ilgili olarak hakkında yöneltilen suçlamalar, kendisinin savunmaları ve nihayetinde verilen kararlar üzerinde durulmaktadır. Araştırmanın kaynağını Osmanlı arşiv belgeleri ile birinci ve ikince elden kaynaklar oluşturmaktadır.

\section{Halep Valiliği Surasındaki Suçlamalar}

\subsection{Rüşvet Aldığı İddiası}

Vecîhî Paşa'nın Bosna Valiliği sırasındaki suçlamalar, yargılamalar padişah ve hükümet nezdinde imaj kaybına uğradığını göstermektedir. Bosna'daki görevinden azledildikten sonra bir süre İstanbul'da ikamet etmek mecburiyetinde kaldı. Sonrasında bir takım yeni görevlere tayin edildiyse de önceki vazifelerine nispetle bunların oldukça kısa süreli olduğu görülmektedir. Önce 3 Haziran 1841 'de Konya Valiliğine ${ }^{7}$ ve beş ay sonra Diyarbekir, ${ }^{8}$ Eylül 1842 'de Halep Valiliğine tayin edildi. ${ }^{9} \mathrm{Bu}$ görevi sırasında halktan birkaç bin kese rüşvet aldığ hakkında dedikodular yayıldı. İstanbul'da yankı uyandıran bu dedikoduların etkisiyle Şubat 1845 'te Sayda Valiliğine getirilmek suretiyle Halep'ten uzaklaştırıldı. ${ }^{10}$ Ancak rüşvet alındığına yönelik resmî surette herhangi bir suçlama veya şikâyetin yapılmadığı görülmektedir.

Buna rağmen meselenin peşini bırakmak istemeyen Sadâret makamı, Halep ve Urfa Valiliğine getirilen Osman Paşa'ya meselenin içyüzünün gizlice araştırılmasını emretti. İncelenmesi gereken hususlar şu şekilde sıralanmaktaydı: Vecîhî Paşa'nın valiliği süresince rüşvet veya diğer adlar altında birkaç bin kese haksız yere para aldığı rivayetinin ve istihbaratının araştırılması, bu gibi yasak olan işleri yapıp yapmadığının, böyle paralar alınmış ise nerelerden, kimlerden ve ne şekilde alındığının soruşturulması, bu çalışmalar yapılırken gizliliğe önem verilmesi, adalet ve hakkaniyetin gözetilmesi, dürüst ve garaz sahibi olmayan kişilerin bilgilerine başvurulması, sonucun ayrıntılı olarak bildirilmesi.

Osman Paşa'nın, Sadâret makamına takdim ettiği tezkerede yer alan bilgilere göre yapılan ön soruşturmanın sonuçları şu şekilde sıralanabilir: ${ }^{11}$

- Halep'te Vecîhî Paşa'nın bir hayli miktarda akçe aldığı söylenmekte ise de hiç kimse açığa çıkıp da verdiği parayı geri istemiş veya bu konuda bir talepte bulunmuş değildir.

- Yakın zamanda Kilis kazasının vergilerinin muhasebeleştirilmesi sırasında Vecîhî Paşa'nın bu kazadan kudûmiye ve hidmet-i mübâşiriye adıyla veya başka adlarla 200.000 kuruştan fazla aldığ 1 tespit edilmiş ve bu para da Kilis vergi tahsilatından karşılanarak borç bakaya gösterilmiş, verilen meblağın tekrar kaza ahalisinden tahsili kanuna aykırı olduğundan,

\footnotetext{
${ }^{6}$ Zafer Gölen, “Bosna Valisi Mehmed Vecîhî Paşa'nın Muhakemesi”, Belleten, C.LXXVI, S.277, Aralık 2012, s.849-877.

${ }^{7}$ Ahmed Bâdî, Age, s.1048.

${ }^{8}$ BOA, I. DH, 47/2317 (16 Ramazan 1257 / 1 Kasim 1841).

${ }^{9}$ BOA, Irade - Dâhiliye, 66/3251 (27 Recep 1258 / 3 Eylül 1842).

${ }^{10}$ Ahmed Bâdî, Age, s.1048. Mehmed Süreyya, Age, C.V, s.1655'te Muharrem 1259'da (Ocak 1843) Halep'ten azledildiği yazılı olmakla birlikte Sayda Valiliği'ne atandığı bilgisi yer almamakta, Rebiulevvel 1259'da Belgrat'a atandığı ifade edilmektedir. Hâlbuki Belgrat Muhafızlığına atanması daha sonradır. BOA, A.DVN., $15 / 39$ (1 Rebiulevvel 1262 / 29 Mart 1846). Nitekim Mayıs 1845 ve Ekim 1845'te Sayda Valisi olduğuna dair bilgiler arşiv belgeleriyle teyit edilebilmektedir. BOA, A.MKT.MHM., 1/72; I.MVL, $3 / 57$.

${ }^{11}$ BOA, A.MKT, 37/8 (5 Rebiulevvel 1262 / 3 Mart 1846).
} 
hiçbir şüpheye mahal burakmamak için Kilis'in muhasebesi Halep Meclisi'ne havale olunarak daha kapsamlı inceleme yapılmaktadır. Sonuçlandığında durum arz edilecektir.

- "Emvâl-i mirîyeden her kimin zimmetinde matlûbât-1 mîriye var ise hane ve emlâki sattırılarak tahsil olunması"nı dair gelen Sadâret emri icabınca bütün ertelenmiş olan devlet alacaklarının tahsiline bir kat dahi gayret olunduğunda eski Halep Naibi Ahmed Bahaeddin Efendi'nin zimmetinde 400.000 kuruştan olduğu belirlenmiştir. Adı geçen sıkıştırılarak bütün malına ve mülküne el konularak satılmasına karar verildiği, hem servetini hem de akranları arasında namus ve itibarını kaybedeceği, bundan dolayı büyük üzüntü yaşayacağı hatırlatıldığında, bu arada Vecîhî Paşa'nın da Sayda Valiliğinden uzaklaştırıldığı haberi geldiğinden, her şeyi anlatmaya mecbur kalmıştır. Söylediğine göre belirtilen meblağ zimmetine geçirmediği için borcu bulunmamaktadır. Vecîhî Paşa kendisini askerî hizmette istihdam ettiğinden dolayı, "Sen müdürlükten haylıca temettü ettin" diyerek Halep hazinesinden para istenmesi için yazı yazdırmış, gelen meblağın tamamına el koymuştur.

- Vecîhî Paşa'nın bu şekilde haksız yere para aldığına dair iddialar muhtelif kimselerden uygun şekilde sorulmuş ise de, hiç kimse bunu doğrulayacak ifade kullanmamıştır. Bazı insanların alacak iddiasında ve geri istemek derdinde olmadıkları, olup bitmiş bir madde olduğunu belirterek biraz şey verdiklerini ima ettikleri, fakat miktarını gizlettikleri gözlemlenmiştir. Hatta Urfa eyaletinden redif askeri yazılıp toplanması sırasında Vecîhî Paşa'nın buraya gittiği sırada da bir takım akçeler aldığı rivayet olunduğundan ve aynı tarihlerde Arabistan Ordusu Müşiri Namık Paşa da Urfa'da bulunduğundan konuya dair malumatı bulunacağı düşüncesiyle kendisiyle Halep'te görüşülmüştür. Namık Paşa, gerçekten de redif maddesinden dolayı akçe alınmış olduğunun söylendiğini, fakat kimsenin gelip iddia ve şikâyette bulunmadığını, bütün araştırmalara rağmen herhangi bir delile rastlanmadığını ifade etmiştir.

- Vecîhî Paşa'nın rüşvet alması konusunda Halep Meclisi azasının malumatı olacağı düşünülmekte ise de sükût etmeyi seçmekte ve herhangi bir ihbarda bulunmamaktadırlar. Onun Halep'ten ayrıldığı sırada hesapların ibra edildiğine ve kendisinin "hüsn-i hâline şahâdet olmak üzere" mühürlü mazbata vermelerinden kaynaklandığı mantıken tahmin edilmektedir. Bu rüşveti verenler her ne suretle vermişler ise aralarında uzlaşma olduğundan hiç kimsenin söylemeyeceği anlaşılmaktadır.

Vecîhî Paşa'nın rüşvet aldığına dair tek şahit olan Ahmed Bahaeddin Efendi uzun bir süre sonra İstanbul'a gitmiş ve bir süre de orada kalarak ilgililere bildiklerini iletmiş ise de, ${ }^{12}$ söyledikleri başka delil ve şahitler tarafindan desteklenmediğinden olsa gerektir ki, Vecîhî Paşa'ya herhangi bir müeyyide uygulanmamıştır.

\subsection{Cevrîzâde Süleyman Ağa'nın İddiası}

Vecîhî Paşa'nın Halep Valiliği sırasında nüfuzunu kullanarak kendisine ait binaları ve dalyanı oldukça düşük fiyata satın aldığını iddia eden ve Antakya'nın ileri gelen ailelerinden olan Cevrîzâde Süleyman Ağa bin İbrahim Ağa hem Sadâret makamına hem de Valide Sultan'a arzuhaller sunarak perişanlığının ve mağduriyetinin giderilmesini talep etmişti. Süleyman Ağa'nın iddiasına göre; Vecîhî Paşa'nın adamı olan Halim Bey kendisini tazyik edip korkutarak, başka çaresi olmadığından senelik otuz beş bin kuruş gelir getiren malikânesini zorla alıp bedeli diye yüz altmış bin kuruş ödemiş, ayrıca kendisine ait olan ve senelik kırk beş bin kuruş hasılatı olan dalyanı da, "malikâne dâhilindedir" diyerek yirmi bin kuruş bedelle zapt

${ }^{12}$ BOA, I.MVL, 116/14 (20 Şaban 1268/9 Haziran 1852).

$$
\text { (1) }
$$


eylemiştir. Bu yüzden büyük gadre uğradığını belirterek gasp edilen haklarının iade edilmesini talep etmiştir. ${ }^{13}$

Süleyman Ağa'nın dilekçesi Meclis-i Vâlâ marifetiyle Anadolu Kazaskerliğine havale edilmiștir. Burada yapılan muhakemede dilekçe sahibi Süleyman Ağa ve Vecîhî Paşa ile oğlu İsmail Sadık Kemal Efendi'nin vekili olan Divan Kâtibi Kasım Şefik bin Ali Ağa hazır bulunmuşlardır. Mahkemede taraflar dinlenmiş, sunulan evrak ve deliller incelenmiş, nihayetinde Süleyman Ağa'nın iddialarının hukuken boş ve yersiz olduğu tespit edilmiş; ancak fakirliğinden dolayı merhamet gösterilerek yirmi bin kuruş verilmek suretiyle davadan vazgeçmesi teklif edilmiş, davacı da bunu kabul etmiş̧tir. Bunun üzerine Süleyman Ağa, Meclis'i Vâlâ'ya çağrılarak burada bir kere daha dinlenmiştir. Konuya ilişkin olarak hazırlanan 22 Ağustos 1847 tarihli arz tezkeresinde; "Bu suretle tesviyesine memnûnen ve müteşekkiren razı olmuş olduğunu ağa-yı mûmâ-ileyh şifâhen dahi Meclis-i Vâlâ-yı mezkûrda beyân ve ifâde eylemiş..." denilmektedir. ${ }^{14}$

Bu davayla ilgili başka bilgiye rastlanmamıştır. Süleyman Ağa çok yüksek getirili olan mal varlığını baskı ve tehdit ile düşük fiyata sattığını söylemektedir. Ancak şikâyetçi olduğu sırada Vecîhi Paşa'nın Halep Valiliği devam etmektedir. Şayet Paşa'dan ve adamlarından kaynaklanan bir korku mevcut ise bir şikâyetin, hele de İstanbul'a gidilerek hem Sadâret makamına hem de Valide Sultan'a arzuhal sunmanın çok zor olacağı akla gelmektedir. Ancak arzuhalinde her şeyi anlatan Süleyman Ağa, şikâyetçi olmasını engelleyici herhangi bir durumdan söz etmemektedir. Muhtemelen özel sebeplerle çok değerli emlâkini oldukça ucuz fiyata satmak durumunda kalmasından sonra, biraz daha para elde edebilmek maksadıyla böyle bir davaya kalkışmış olup eğer bu tespit doğru ise amacına ulaşmış demektir.

Öte yandan Vecîhî Paşa gayrimenkul almaya, yatırım ve ticaret yapmaya meyilli devlet

Volume 12

Issue 2

A Tribute

to Assoc.

Prof. Dr.

İlknur

Mangir

Karagöz,

April

2020

adamlarından idi. Elde ettiği gelirleri bu şekilde değerlendirdiği görülmektedir. Nitekim hükümet tarafından malları müsadere edilen Emin Efendi'ye ait üç adet çiftlikten biri olan Ayastefanos çiftliğini padişahın izniyle 175 kuruşa satın alması,${ }^{15}$ Ankara'da gayrimenkuller aldığı gibi İstanbul - Kanlıca'da yalı köşkü yaptırması, ${ }^{16}$ Antakya'daki dalyan ile birlikte bir sabunhâne sahibi olması bunu göstermektedir. ${ }^{17}$

\subsection{Bir Alacak - Verecek Davasına Adının Karışması}

Vecîhî Paşa'nın Halep Valiliği sırasında buraya bağlı olan ve o tarihte müstesna statüde bulunan Harput eyaletinin mütesellimliği1258 (1842-1843)yılında eski Malatya mütesellimi Sülükîzâde Mehmed Ağa'ya ihale edilmişti. Bundan dolayı Mehmed Ağa eski usul gereğince mali ilişkilerde bulunduğu Sarraf Kigork'tan Vecîhî Paşa'ya elli bin kuruş caize verilmesini istemiştir. Sarrafta denileni yapar. Ancak ikili arasında uzun süredir devam eden borç - alacak ilişkisinden dolayı anlaşmazlık ortaya çıkar. Sarraf Kigork alacaklarına karşılık Mehmed Ağa’nın arazi ve emlâkini rehin olarak elinde tutmaktaydı. Borçların çeşitli bölümlerine muhtelif şekillerde itiraz eden Mehmed Ağa, özellikle Vecîhî Paşa’ya ödenen elli bin kuruşla

${ }^{13} B O A, \dot{I} . D H, 154 / 7995$ (Belge-1).

${ }^{14} B O A, \dot{I} . D H, 154 / 7995$ (Belge-2, 10 Ramazan 1263 / 22 Ağustos 1847).

${ }^{15}$ BOA, $H H, 1328 / 51808$ (29 Zilhicce 1252 / 6 Nisan 1837).

${ }^{16}$ BOA, C.ML, 34/1554; I.DH, 149/7738. Kanlıca koyundaki Mihrabat korusu ile birlikte iki büyük bir küçük yalı inşa edilmiş, bunlardan bir tanesi Paşa'nın kızı Necibe Hanım'a intikal etmiş, o da oğlu Nusret Bey ile evlendirdiği Kavalalı Mehmed Ali Paşa'nın torunu Abdülhalim Paşa'nın kızı Rukiye Hanım'a hediye etmiştir. Bundan dolayı sonradan Prenses Rukiye Yalısı adıyla meşhur olmuştur.

17 BOA, A.MKT.DV, 104/81. Valilerin kazandıkları paraları ticarette değerlendirmeleri memuriyetlerine engel sayılmamaktaydı. Bu şekilde bazı valilerin ticarî işletme sahibi oldukları, bu işletmeleri birtakım elemanlar aracılığıyla işlettikleri veya kiraya verdikleri görülmektedir. Meselâ Yusuf Paşa'nın Selanik’te bir kahvehanesi olup kiraya vermekteydi. A.MKT.DV.,132/42. 
ilgili olarak herhangi bir talimatı olmadığını, rızası ve ruhsatı dışında verildiğini, dolayısıyla bu para ile faizinin (güzeşte) kendisine borç yazılmaması gerektiğini iddia etmiştir. İhtilaf konusu ile ilgili olarak Sadâret - Meclis-i Vâlâ - Maliye Nezâreti- Harput Valiliği arasında uzun süre çeşitli yazışmalar yapılırken ikili arasındaki alacak-verecek davasına Vecîhî Paşa'nın da adı karışmış olur. Nihayetinde gerek Harput Meclisi gerekse Meclis-i Muhasebe-i Maliye tarafından, davanın Mehmed Ağa tarafından ısrarla reddedilen "elli bin kuruşun kendi emriyle ödendiği / ödenmediği” hususunun, Sarraf ile Vecîhî Paşa arasında çözülmesi gerektiğine karar verilmiştir. ${ }^{18}$

Hadisenin üzerinden on yıldan fazla bir zaman geçtikten sonra 1274 başlarında (Ağustos 1857) Meclis-i Muhasebe'de kurulan bir komisyon huzurunda yapilan muhakemede, Sarrafin kendisinden talebi olmadığı halde Vecîhî Paşa, elli bin kuruşu kendisinin ödeyeceğini vaat eder. Böylelikle bu konu ikili arasındaki alacak - verecek meselesinden ayrılmış olur. Nihayetinde yapılan hesaplama sonucunda Mehmed Ağa'nın Sarrafa 127.500 kuruş borçlu olduğuna, borcun Harput'ta nakden ödenmesi halinde rehin tutulan malların iade edilmesine, aksi halde gayrimenkullerin satılarak borçların tasfiye edilmesine karar verilmiştir. ${ }^{19}$

Vecîhî Paşa elli bin kuruşu Sarraf Kigork'a ödeyeceğini taahhüt etmekle bu meblağı aldığını kabul etmektedir. Ödemenin Mehmed Ağa'nın emriyle ödenip ödenmediği hususu bir tarafa bırakılacak olursa, Sarraf'ın da açıkça belirttiği üzere ödenen para Mehmed Ağa'nın aldığı iltizâmdan dolayı câize olmak üzere verilmiş olduğu gerçeğidir. Câize, Osmanlı tarihinde y1llarca devam eden ve Tanzimat yenilikleriyle bertaraf edilmek istenen bir uygulama idi. Herhangi bir makama tayin edilen kişi üst makamlara uygun şekilde hediye vermek zorundaydı. Verilen hediyenin derecesi tayin edilen makamın seviyesine göre değişmekteydi. ${ }^{20}$

Burada mütesellimlikten söz edildiğine göre Harput'ta henüz Tanzimat ilkeleri uygulanmaya başlanmamış demektir. ${ }^{21}$ Hem Sarraf'ın dilekçesinde burasının müstesna surette yönetildiğini ifade etmesi, hem de konu ile ilgili görüşmelerde Maliye, Meclis-i Vâlâ ve Sadâret yetkililerinin câize aldığı için Vecîhî Paşa'yı suçlamamaları ve bunu bir rüşvet alma işlemi olarak görmemeleri bundan kaynaklanmış olmalıdır. Öte yandan Tanzimat'la birlikte caize uygulamasının kaldırılmasından yararlanmak isteyen Mehmed Ağa, kendi emriyle verilen bu meblağ i inkâr etmek suretiyle borcunun bir bölümünden kurtulmak istemiş olduğu akla gelmektedir.

\section{Belgrat Muhafızlığı Sırasındaki Şikâyet}

Vecîhî Paşa ile ilgili bir suçlamada, kendisinin Halep ve Sayda valilikleri ile Belgrat muhafızlığı sırasında sandık sarraflığını yaptığını ifade eden Avrupa tüccarından ve Rum milletinden olan Anastas tarafından yapılmıştır. O, verdiği sarraflık hizmetinden dolayı görülen muhasebeleştirme işleminde haksızlığa maruz bırakıldığını, konunun Meclis-i Vâlâ, Meclis-i Muhasebe veya uygun görülecek bir yerde, Paşa'nın hazinedarları olan oğulları Kemal ve Salih beylerin de katılımıyla yeniden görüşülmesini talep etmiştir. Şikâyetçi tarafından verilen iki ayrı dilekçede dile getirilen iddialar şu şekilde özetlenebilir:"2 Vecîhî Paşa'nın Halep ve Sayda'daki görevleri süresince bu eyaletlerdeki gelir ve giderler mahallinde mümkün mertebe muhasebeleştirilmiştir. Ancak şartlar gereğince bazı pürüzlü maddeler kalmış olup hesabına

\footnotetext{
${ }^{18}$ BOA, A.MKT.NZD, 155/58; A.MKT.MVL, 77/55, A.DVN, 112/62, I.MVL, 302/25.

${ }^{19}$ BOA, A.M, 16/59.

${ }^{20}$ Câize hakkında özet bilgi için bkz. Mustafa Uzun, "Câize”, DİA, C.VII, İSAM Yayınları, İstanbul 1993, s.28-29.

${ }^{21}$ Musa Çadırcı, "II. Mahmud Döneminde Mütesellimlik Kurumu, Dil ve Tarih - Coğrafya Fakültesi Dergisi, C.XXVIII, S.3-4 (Temmuz - Aralık 1970), s.287-296; Yücel Özkaya, XVIII. Yüzyılda Mütesellimlik Müessesesi”, Dil ve Tarih - Coğrafya Fakültesi Dergisi, C.XXVIII, S.3-4 (Temmuz - Aralık 1970), s.369-390.

${ }^{22}$ BOA, İ.MVL, 52/32, 51/33 (Belge-1).
} 
göre 210.000 kuruş alacağı bulunmaktadır. Paşa'nın Belgrat muhafızlığından ayrıldığı sırada burada yapılan muhasebeleştirme işleminde, Halep ve Sayda'daki bazı pürüzlü maddeler dâhil edilmişken bazıları mükerrer kabul edilerek yok sayılmıştır. Ayrıca kendisinde bulunan Hafız Paşa'nın verdiği ve bedeli 68.000 bin kuruştan fazla olan bir adet tahvil senedi de "sarrafa emanet verilmiş" denilerek hesaba katılmamıştır. Beş senelik ücreti verilmediği gibi 10.000 kuruş borçlu çıkartılıp ve kendisinden zorla bir tane ibra senedi alınmak suretiyle mağduriyetine sebebiyet verilmiştir.

Vecihî Paşa, Sadâret makamı tarafından söz konusu iddialar ile ilgili olarak kendisine sorulan sorulara, ${ }^{23}$ oldukça ayrıntılı şekilde kaleme aldığı 23 Ağustos 1847 tarihli yazısıyla cevap vermiştir. Esasında Anastas'ı tanımadığını, ticaretle meşgul iken idare edemeyip zor duruma düşmesi üzerine onunla tanışıklığı olan kayınpederi Hacı Mesud Ağa'nın münasip hizmette istihdam edilmesi yolundaki ricası üzerine, lüzumu olmamasına rağmen 600 kuruş maaş ile çalıştırıldığını, geçen sene İstanbul'a vardığı sırada mahsuplaşmanın yapılması suretiyle karşılıklı ibra senetleri verilerek alacak vereceğinin kalmadığını belirterek sonraki süreci özetle şöyle anlatmaktadır: ${ }^{24}$

Belgrat'a memuriyetim sırasında benimle birlikte gelmek istemiş ise de "lüzumu olmadığı" cevabı verilmişti. Sonradan kendisini idare edemediğini belirtip emrimdekilerden bazılarının iltiması üzerine "isterse gelsin" denilmiş ve 400 kuruş maaş verilmiştir. Maaştan dolayı bir akçe alacağı bulunmamaktadır. Ayrıca Belgrat'tan ayrıldığım sırada zimmetine bir miktar akçe geçirmiş olduğu anlaşılmış olduğundan memurlarım marifetiyle hesapları görülerek otuz-kırk bin kuruş miktarı zimmeti belirlenmiştir. Anastas ise bu miktar zimmeti olmadığını, Belgrat'a benden sonra gelmiş olduğundan gerek yol masrafı ve gerek Belgrat'ta ailesiyle beraber bulunduğunu dile getirerek 400 kuruşla idare edemediğini, on beş - yirmi bin kuruş yemiş olduğunu, kalanın muhasebedeki yanlışlıktan kaynaklandığını ifade etmiştir. Yanlışlığın ortaya çıkarılması için İslâm ve Sırplardan birkaç tüccar bulunarak muhasebe yapılmasını talep ettiği için, meselenin tam anlamıyla tespit edilebilmesi maksadıyla "Yalnız tüccar değil, mahkeme huzurunda Belgrat meclis azaları dahi mevcut bulunarak muhasebe görülsün" denilerek Belgrat Naibi, Müftüsü, Meclis azaları, Müslüman ve Sırplardan bir takım tüccar hazır oldukları halde bütün makbuzlar ve defterler tek tek incelenmiştir. Nihayetinde kendisine 29.900 kuruş zimmet çıkarılmıştır. Konuya ilişkin olarak açıklama yapması istendiğinde sorulduğunda yol masrafları ile diğer masraflara harcadığını belirtip birazının indirilmesini istemiştir. Belgrad'a sonradan gelmesi dolayısıyla bir miktarı indirilmiş, 8.000 kuruşunu ödemiş, 10.000 kuruş için de borç senedi düzenlenmiştir. Böylece tarafımda kat'iyen bir akçe alacağ 1 kalmamıştır. Gerek benim gerekse oğullarımın zimmetlerini ibra ettiğini kendi el yazısı ile yazıp imzaladığı, hazır olanların da mühürlediği bir adet Rumca senet vermiştir. Ben de kendisine yine bir adet ibra senedi vererek alakamı kestim. Bahsedilen senetler kapu kethüdam vasitasıyla Sadâret makamına sunulmuştur. Bu şekilde mahkeme, memleket meclisi azaları, İslâm ve Sırp tüccarları huzurunda yapılan muhasebeleştirmenin haksızlığa yol açmayacağı aşikârdır. Anastas'ın vermiş olduğu üç kıta ibra senedinden sadece ikisini Saltanat makamına verip diğerini hem cinsi olan Sırp idaresine teslim etmesini can güvenliğine bağlaması sırf yalandan ibarettir. Hafız Paşa'nın tahvili diye iddia ettiği 68.000 kuruştan fazla olan kısım, benden önce Paşa'nın Belgrat emvalinden istikraz ettiği akçenin tahvili demek olup benimle bir ilgisi bulunmamaktadır. Öte yandan maaşının az olduğunu iddia edemez, çünkü zorla tutulmayıp işine gelmediği halde bırakır giderdi.

${ }^{23}$ BOA, A. MKT, 92/30 (23 Şaban 1263 / 6 Ağustos 1847).

${ }^{24}$ BOA, I. $. M V L, 51 / 33$ (Belge-2). 
Vecîhî Paşa savunmasını, konunun Belgrat'taki Müslüman ve Hıristiyanlar tarafından bilindiğini gerekirse Belgrat hâkimine, müftüsüne, meclis azalarına, İslâm ve Sırp tüccarlarına ve hatta askerî yetkililere "lütfen ve merhameten istilâm ile icâbına (bakılmasını)" rica ederek bitirmiştir.

Hükümet, Belgrat'ta görülen muhasebe işleminin yolunda ve hakkaniyet çerçevesinde olup olmadığının araştırılmasını Meclis-i Ticaret'e havale etmiştir. Gerekli incelemelerin yapılmasından sonra da evrakların Meclis-i Vâlâ'ya gönderilmesini emretmiştir. ${ }^{25}$ Sonraki dönemde Vecîhî Paşa'ya yönelik bu mesele ile ilgili olarak herhangi bir suçlama söz konusu olmamıştır.

\section{Ankara Valiliği Sırasındaki Suçlamalar}

Vecîhî Paşa hakkındaki en kapsamlı şikâyet ve buna paralel olarak muhakeme süreci Ankara Valiliği sırasındaki faaliyetleri sebebiyle söz konusu olmuştur. Kendisi Ankara'da iki dönem valilik yapmıştır. İlk valiliği 3 Ağustos 1848 'de tarihinde başladı, daha sonra Bozok mutasarrıflı̆̆ 1 da uhdesine verildi. ${ }^{26}$ Bağdat'ın öneminden dolayı 19 Aralık 1850 tarihinde buranın valiliğine getirildi. ${ }^{27} \mathrm{Bu}$ görevde bir buçuk yıl kadar çalıştıktan sonra 19 Mayıs 1852 tarihinde yeniden Ankara Valiliğine tayin edildi. Uhdesine Bozok, Çankırı ve Kayseri sancakları da verildi. Mayıs 1855 'e kadar üç yıl süreyle bu görevi sürdürdü. ${ }^{28}$

Vecîhî Paşa'nın görev yaptığı sıralarda Orta Anadolu Bölgesi uzun zamandan beri konargöçer aşiretlerden kaynaklanan asayiş problemleri sebebiyle güvensiz durumdaydı. Hatta İngiltere'nin Kayseri konsolosu "Tanzimat-1 Hayriye'nin bu havalide ismi var cismi yok" diyerek can ve mal emniyetinin olmadığına vurgu yapmaktayd $1 .{ }^{29}$ Tanzimat'ın yönetim kadrosu aşiretlerin idaresinde merkezî otoriteyi etkisiz hale getiren ağalık, beylik kurumunun kaldırılmasından yeni bir idarî yapılanmaya gitmeye kadar birçok konu tartışmış ise de bir karara varamamıştı. Bu sırada asayişin sağlanabilmesi için konar-göçerlerin iskânı konusu gündeme alındı. İskân konusunda öncelik Orta Anadolu'ya verildi. Vecîhî Paşa bir taraftan konar-göçer aşiretler içerisinde bulunan cinayet, çocuk kaçırma, hırsızlık, yol kesme, gasp suçlarına bulaşanların yakalanıp yargılanmasını sağlarken, ele geçirilen mal ve eşyayı da sahiplerine iade ettirdi. ${ }^{30}$ Yapılan bu çalışmalar halktan büyük ölçüde destek görmesine yol açtı. Peş peşe Müslüman ve gayrimüslim halkın temsilcilerinden şükran ifadelerini içeren yazılar kendisine ve hükümete ulaşmaya başladı. ${ }^{31}$

${ }^{25}$ BOA, I. $. M V L, 51 / 33$.

${ }^{26}$ Ahmed Bâdî, Age, s.1048; BOA, İ.DH, 225/13448 (14 Safer 1267 / 19 Aralık 1850); 132/3525 (8 Safer 1265 / 3 Ocak 1849). İlk Ankara Valiliğinde maaş1 elli bin kuruş olarak belirlenmişti ki, döneme göre oldukça iyi bir meblağ idi. $\dot{I} . D H, 179 / 9803$ (6 Şevval 1264 / 5 Eylül 1848).

${ }^{27} B O A, \dot{I} . D H, 225 / 13448$.

${ }^{28}$ BOA, A.MKT.MHM, 46/79; A.MKT.NZD, 55/33; I.MVL, 164/52; C.DH, 296/14752. Vecîhî Paşa Ağustos 1852'de Ankara Valiliğinden alınarak Kürdistan Valiliğine tayin edilmesine dair bir karar çıkmış ide de (BOA, I.DH, 256/15805 (20 Şevval 1268/ 7 Ağustos 1852), daha sonra Vecîhî Paşa'nın müracaatı üzerine iptal edilerek görevine devam etmesi sağlanmıştır. BOA, A.MKT.UM. 104/90 (3 Zilkade 1268 / 19 Ağustos 1852); BOA, I.DH, 258/15909 (25 Zilkade 1268/ 10 Eylül 1852). Kemal Paşa eserinde bu iptalin halkın talebi üzerine gerçekleştiğini aktarmaktadır. Age, ek sayfa.2. Mehmed Süreyya, Age, C.V, s.1655'te tayinin iptalinden söz etmemektedir.

${ }^{29}$ Abdullah Saydam, “Orta Anadolu'da Aşiret İskânları (1839-1853), Prof. Dr. Bayram Kodaman'a Armağan, ed. M. A. Ünal, Eser Matbaas1, Samsun 1993, s.236.

${ }^{30}$ Geniş bilgi için bkz. Agm, s.227-256.

${ }^{31} B O A, A . D V N, 46 / 60$. Örneğin Yozgat reâyâsı, eşkıyanın zulmünden kurtarıp can ve mal güvenliklerini sağlayan Bozok Valisi Vecihi Paşa'dan memnun olduklarını, başka yerlere sürülmüş olan suçluların geri getirilmesini istemediklerini İstanbul Rum Metropolitliği aracılığıyla hükümete iletmiştir. BOA, A.DVN, 58/82 (25 Cemaziyelevvel 1266 / 8 Nisan 1850). Başarısından ötürü Paşa'ya vükelâlık nişanı verilmiştir. $B O A, \dot{I} . D H$, 214/12530; A.MKT.UM, 15/86; A.MKT.NZD, 8/43. 
Asayişin sağlanması için daha etkili yolun konar-göçerlerin iskânıyla sağlanabileceğini düşünen Paşa'nın bu konudaki önerisi dağınık iskânın sağlanmasıydı. Aşiretlerin kurulu düzeninin toplu iskânlarla bozulamayacağını, bu yüzden mevcut köylere ikişer üçer hane şeklinde dağıtılmaları halinde kısa zamanda yerleşik halk ile konar- göçerlerin kaynaşacağını belirterek böyle bir modelin uygulanması için izin istedi. Bâbıâli, teklifini kabul etti ve geniş yetkilerle kendisini bu iş için görevlendirdi. Vecîhî Paşa, bu görevi icra ederken aynı zamanda nizamiye ordusu için kur'a işlemlerinin gerçekleştirilmesi, redif birliklerinin yazımı ve sevki gibi işlerle uğraştı. Aşiretlerle mücadelesinde ihtiyaç duyulan silahlı gücü de düzenli kuvvetlerin yetersizliği sebebiyle devlete sadık olan aşiretler ile belirli bir ücret karşıllı̆ istihdam edilen başıbozuklardan karşılamaktaydı.

Uzun süren bu görevi sırasında sık sık hakkında şikâyetlerin yapıldığı görülmektedir. Şikâyetler genellikle ya iskân edilen, bir şekilde eski düzene dönmelerine meydana verilmeyen aşiret ileri gelenlerinden veya Vali ile uyum sağlayamayan mahallî yöneticilerden kaynaklanmaktaydı. Örneğin önemli suçlamalardan birisini Cihanbeyli aşiretinin müdürü olan Alişan Bey yapmıştı. Alişan Bey, Vecîhi Paşa'nın emirleri doğrultusunda askeri faaliyetlerde de yer aldığını, ancak daha sonra haksızlığa uğratıldığını iddia ederek Sadâret makamına arzuhal sunmuştu. Arzuhalde yer alan bilgilere göre; Rişvan aşiretine mensup bin kadar hanenin iskân olunması hususunda Vecîhî Paşa, kethüdası Halim Bey ile Alişan Bey'i görevlendirmiş, Cihanbeyli aşiretinden temin edilen birkaç yüz süvari ile bunların tamamı bir mesele çıkmadan iskân ettirilmişti. Bu sırada Halim Bey aşiretin bazılarından hediye vesaire almış, Alişan Bey'in yapmaması yolundaki uyarılarını dinlememiştir. Daha sonra bunu duyan Vecîhî Paşa, Kayseri Meclisi'nde bunlanı muhakeme ettirmiş, Halim Bey’in aldığı hediyeleri geri verdirilmiş, Alişan Beyi de onun refakatinde bulunduğundan dolayı "Aldığı vakit niçün men' etmedin" diyerek azarlamış; "Kethüdanız bulunduğu cihetle men'ine muktedir olamadım" diye cevap verilince, Paşa; "Mademki Halim Bey almış, sen dahi refakatinde bulunduğun içün kabahatte müştereksiniz" yollu cevap vermiştir. ${ }^{32}$

Alişan Bey; Halim Bey'in aldığ 1 hediyeden kesinlikle kendisinin faydalanmadığını, bir akçe dahi kabul etmediğini, bu hususta Vali tarafından istihdam olunanlar ile dairesinin cümlesinin ihya olduğunu, buna karşl1ık sevk olunan neferlere istihdam edildikleri müddetçe bir akçe verilmediğini, yerleştirilen aşiretlerin mallarının ellerinden alındığını, bunlar ikişer üçer hane iskân olunduğundan kimsenin hallerini ifadeye mecallerinin kalmadığını, Halim Bey'le ilgili konunun ortaya çıkmasının Valinin dairesindeki görevlilerin ona olan düşmanlığından kaynaklandığını, Vali tarafından hizmetlerinden ötürü defalarca tebrik edilmiş iken, birkaç yüz süvari ile bir senedir yem ve yiyecekleri kendi tarafından olmak üzere meccanen islahat-1 mülkiye için padişahın hizmetinde bulunup mükâfat beklerken Vecihî Paşa'nın kendisini cezalandırmak istemesinin külliyen adalete ve hakkaniyete aykırı olduğunu belirterek İstanbul'a çağrılıp padişah hizmetinde istihdam olunmasını talep etmiştir. ${ }^{33}$

Bu sıralarda hükümet nezdinde Vecîhî Paşa'nın itibarı son derece üst düzeyde idi. Yı1larca bir türlü üstesinden gelinemeyen konar-göçer aşiretlerden kaynaklanan asayiş meseleleri bir hal yoluna girmişti. Dolayısıyla Alişan Bey'in bu arzuhalinin merkezde çok ciddiye alınmadığ 1 anlaşılmaktadır.

Vecîhî Paşa'nın Ankara'da asıl sıkıntı çektiği dönem valiliğinin ikinci safhası idi. Gerek önceki valiliği döneminde gerekse ikinci safhada, bilhassa aşiretlerden kaynaklanan

\footnotetext{
${ }^{32}$ BOA, A.MKT, 232/23 (11 Zilhicce 1265 (28 Ekim 1849).

${ }^{33}$ Aynı belge.
} 
şikâyetlerin artması üzerine İsmet Paşa, Anadolu tarafının teftişi için görevlendirildi. ${ }^{34} \mathrm{O}$, sunduğu bir raporda Paşa'nın Tanzimat usulüne aykırı olarak rüşvet almak gibi suçlara bulaştığını yazdı. Bunun üzerine Sadâret makamı, ithamlar hakkında Vecîhî Paşa'dan bilgi istedi. O da yine çok ayrıntılı biçimde hazırladığı yazısında hem kendisini savunmaya çalıştı hem de İsmet Paşa'ya yönelik bazı suçlamalarda bulundu. Yazdıkları şu şekilde özetlenebilir: ${ }^{35}$

1. İsmet Paşa, benim Yozgat'ta bulunduğum günlerde güya Tanzimat-1 Hayriye'ye, padişahın adalet anlayışına aykırı olarak pek çok haller vuku bulduğundan başka; cami ve köprü tamiri, memleket ve müdürlerin masrafları adıyla hazineden 244.763 kuruş alıp bunun 100.000 kuruşunu zimmetime geçirerek kethüdam ve diğer dairem halkıyla Meclis azaları arasında taksim ettiğimi yazmıştır. Burada gerek asayiş gerekse aşiretlerin iskânı ve yolların emniyeti için gücümün ve aklımın yettiği mertebe çalıştığımdan İsmet Paşa'nın belirttikleri 1stırap ve esef kaynağı olmuştur.

2. İsmet Paşa'nın iddialarının içyüzü şöyledir: Bu masraflar zamanımda yapılmış olmayıp Bozok sancağının havi olduğu kazalar 1256-1263 seneleri arasında maaşsız olarak yerli müdürler marifetiyle idare olunmuştur. 1263 senesinde bunlar azledilerek yerlerine maaşl1 olmak üzere İstanbul'dan müdürler tayin edildi. Maaşları da alınan vergiye zam yapılarak karşılandı. Mahalli meclislerde gelirler ve giderler hesaplandığından maaşsız çalışan müdürlerin uhdesinde birer miktar zimmetleri olduğu ortaya çıktı. Musul Mutasarrıfı Hilmi| Paşa ve Sivas Mutasarrıfı Said Paşa'nın Bozok Mutasarrıflıkları ile Karahisar-ı Şarki Kaimmakamı Galip Efendi’nin Mal Müdürlüğü sırasında zimmetlerinin tahsiline teşebbüs edildiğinde, kendilerinin maaşsız müdür olduklarını, refakatlerinde da kâtip, zaptiye ve sarraf olmadığını, yapılan tahsilatın sancak merkezine gönderilmesi sırasında beygir ücretleriyle ve sair bazı masraflar yaptıklarını iddia ve beyan etmişlerdir. İşte bu masrafların karşılanmasını yahut zimmetlerine mahsup olunmasını veyahut istihdamları müddet için emsali gibi kendilerine de maaş tahsis olunarak zimmetlerinin mahsup k1lınmasını belirtmişlerdir. Bunun üzerine gelecek fermana kadar zimmetleri olduğu gibi bırakılarak, ayrıntılı defterler ile birlikte keyfiyet adı geçen mutasarrıflar ile mal müdürü tarafından saltanat makamına arz olunmuştu. Takdim edilen bu defterler ve evrak araştırıldığında maliye hazinesinde aynen ve Bozok sancağının tahrirat ve maliye kaleminde kayden bulunacağı aşikâr olup sonradan benim Yozgat'ta bulunduğum zamanda buradaki olan bakayanın süratle tahsiline ve gönderilmesine emir verilmiştir.

3. Bunlar böyle iddiada bulunmakta iken padişah tarafından ne denileceği ve kabul olunup olunmayacağı meçhul olacağı halde benim tarafımdan red ile cevap verilmek hakkaniyete muvafik ve memuriyete uygun olmadığından iddia edilen masraflarını gösteren defter ve mazbatalar takdim edilerek gereğinin icra edilebilmesinin fermana bağlı olduğu tarafimdan ifade edilmiştir. Birazının tenzili ile kalanının ödenmesi Maliye Nezâreti'nden bildirildiğinden bir hayli kısmı tenzil edilerek kalanı hem hazineye yük ve hem de adı geçen müdürlere haksızlık olmaması, arada da devlet malının kaybolmaması için adı geçen kaza müdürlükleri kendilerine verilerek tahsis olunan maaşların zimmetlerine mahsup olunması veyahut kabul olan masraflarının zimmetlerine mahsup kılınması hususları yine fermana bağlı olduğundan sonradan Sadâret makamına yazı yazılmıştır.

4. Benim vazifemden birkaç sene evvel vuku bulmuş ve hazine alacağı meydana çıkarılıp iyi bir şekilde tahsil edilmesi sağlanmış iken İsmet Paşa'nın aksini ileri sürmesine mana

\footnotetext{
${ }^{34}$ İsmet Mehmed Paşa, Ramazanoğulları'ndan Necîb Bey'in oğlu olup Enderûn'dan nizzamiye askerliğine geçiş yapmış, 1243'de (1827-1828) miralay, 1249'da (1833-1834) mîrlivâ 1253'te (1837-1838) ferik olmuş, Niş ve Filibe valilikleri gibi önemli görevlerde bulunduktan sonra Muharrem 1267'de (Kasım 1850) Anadolu müfettişliği görevine getirilmişti. Mehmed Süreyya, Age, C.III, s.840-841

${ }^{35}$ BOA, I. MVL, 244/46 (27 Zilhicce 1267 (23 Ekim 1851).
}

to


verilememiştir. Bununla birlikte ben Yozgat'ta ve kendileri de Halep'te oldukları sırada, önceden Ankara mutasarrıflığında iken zulüm ile satın aldı ̆̆ bir çiftliği benim satın almamı istemiş, fakat ben bu çiftliği değerinden pahalıya almak istemediğimden başka, tahsis olunan maaşım ancak masraflarımı karşıladığından dolayı alamayacağımı beyan etmiştim. Galiba bu keyfiyetten dolayı gücendiği için böyle asılsız bir iftirayı tercih etmiştir. Bir de nefsini mukayese etmelerinden kaynaklanmıştır. Mamafih otuz seneden beri devlete hizmet ederek semeresini güzel teveccüh olarak elde edebilmiş olduğum namusumun, Allah korusun böyle bir iftira ile zedelenmesine razı olunmaz. Gerek bu hususta, gerekse İsmet Paşa'nın kuşkularına göre, benim bilemediğim kanunlara aykırı her ne harekât ve muamelem var ise, İsmet Paşa ile muhakememin gerçekleştirilerek adaletin ortaya çıarılmasını talep ederim.

Vecîhî Paşa'nın yazısının sevk süreci takip edildiğinde 22 Muharrem 1268'de (17 Kasım 1851) Meclis-i Vâlâ'ya havale edildiği, iki gün sonraki tarihle de "battal" notunun düşüldügü görülmektedir. $\mathrm{Bu}$ işlemden anlaşıldı̆̆ı kadarıyla İsmet Paşa'nın iddiaları, Vecîhî Paşa'nın yazdıkları, önceden yapılan yazışmalar ve emsalleri dikkate alınarak işlemin tamamlanmasına karar verilmiştir.

İsmet Paşa'nın iddiaları herhangi bir sonuç doğurmasa da Vecîhî Paşa'ya yönelik suçlamalar gittikçe yoğunlaşmıştı. Bu şikâyetlerin en önemlilerinden biri Kayseri Kaimmakamı tarafından gizli olarak yazılmışı. Şikâyetin konusu, iskân edildikten bir süre sonra firar eden Afşar aşireti mensuplarının takip ve yeniden iskânı ile diğer işlerde yolsuzluklar yapıldı̆̆ iddiasına dayanmaktaydı. Yazıda özetle şu iddialar ileri sürülmekteydi: ${ }^{36}$

Vecîhî Paşa Afşar firarîlerini ele geçirip iskân mahallerine göndermek üzere birkaç ay önce Zamantı kazası tarafına gelmişti. Adana Valisi de bu firarileri Çukurova'dan kovaladığından bunlar Vecîhî Paşa'nın merkez edindiği Tomarza köyü yakınındaki Dedebeli denilen mahalle gelmişlerdi. Ancak Vecîhî Paşa üzerlerine varıp yakalamadıktan başka sergerdelerinden Cadıŏlu Ahmed Ağa'yı Göksün yaylağından kendi tarafına istemiş olduğundan adı geçen Ağa refakatindeki dört yüz kadar süvari ile Tomarza'ya gelmek üzere iken Mağara köyü civarında, Afşar firarileri tarafından baskına uğrayıp yüz kadar zaptiye askerin öldürüldüğü, yüz elli askerin de silah ve atlarını aldıkları anlaşılmıştır. Bu olaydan bir kaç gün sonra bahsedilen firariler Dedebeli'nde Vecîhî Paşa'ya on beş dakikalık mahalden savuşarak Uzunyayla tarafina gitmişler, Adana Valisi arkalarından takip edip oradan yine Çukurova tarafına çevirmiş ve Bıçak denilen yerde kırk-elli kadar kadın ve çocuğu ele geçirmiş, diğerleri ise dağlık alana kaçmışlardı. Şimdi her birisi bir tarafta hırsızlık etmektedirler.

$\mathrm{Bu}$ firarilerin ele geçmeyeceklerini anlayan Vecîhî Paşa, iki orduda yapılan masrafları sancaklara paylaştırmakla uğraşmakta ve "Afşar firarilerinden birazı ele geçirilip kalanları da iskân mahallerine gitti" diye yazacak gerçek dışı bir mazbatayı Kayseri Meclisi'nden almaya çalışmaktadır. Bunun için meclis azasından birkaç kişiyi yanına çağırıp taltif etmiştir. Kayseri sancağının ekser iltizamları bu azalar uhdesinde bulunmakta olup validen destek gördüklerinden borçlarını ödememektedirler.

Kayseri ahalisinden Keşzâde Mehmed Efendi'yi iltizam bedelinden dolayı zimmeti olan meblağı tahsil eylemek üzere geçen gün biraz sıkıştırdığımızdan Tomarza'ya kaçmış, daha sonra kendisinin meclise dâhil edilmesi için Vecîhî Paşa'dan bir adet emirname elde ederek gelmiş olduğundan mecburen kabul edilmiştir. Böylelikle devletin alacaklarının tahsilatına mani olunmaktadır.

${ }^{36}$ BOA, A.M, 11/10 (17 Recep 1269 (26 Nisan 1853). 
Afşar'ın tamamen iskân edildiğini belirten mazbatayı ben de mühürledim. Bunların ileride yapacakları saldırılardan halk şikâyetçi olacağından, mühürlemem caiz değil ise de, muhalefet edersem yine bana düşmanlık ederek hakkımda birtakım hakaret icrasına kalkışacağından mecbur kaldığımı arz etmekteyim.

Hemen hemen aynı tarihlerde bir şikâyet de Gedikçik kazasının eski müdürü Ali Rıza Efendi'den geldi. Ali Rıza Efendi, Paşa'nın beş adet emirnamesi üzerine kendi kazasından istihdam etmiş olduğu başıbozuk askerlerinin masraflarını, Gedikçik kazası aşârından karşıladığını, söz konusu meblağın hazineden Vecîhî Paşa marifetiyle alındığını, fakat kendisine bir akçe bile verilmediğini, tamamının Paşa'nın zimmetinde kaldığını iddia etmiştir. Şimdi Gedikçik kazasından ayrılmasıyla birlikte bu meblağın açıkta kaldığını ve kendisine fuzuli yere zimmet çıktığını belirterek böylelikle haksızlığa uğradığını, Vecîhî Paşa'nın halen İstanbul'da olmasından dolayı kendisi ile Meclis-i Vâlâ'da muhakeme olunmak istediğini ifade etmiştir. Bu müracaat Meclis-i Vâlâ'da müzakere edilerek bu hususun bir komisyonda ele alınması kararlaştırılmıştır. ${ }^{37}$ Tıpkı Ali Rıza Efendi gibi bir müracaat da Yeniil aşireti muhtar ve kethüdası Ahmed Kethüda tarafından yapılmış, Vali tarafından kendilerine mezâlim yapıldığını, muhakemeye olunduğu takdirde şifahî olarak da pek çok şey anlatacağını belirtmiş̧ir. ${ }^{38}$ Rişvan aşireti tarafından da kendilerinin haksızlıklara uğradıklarına ve haklarının geri verilmesine dair bazı suçlamaların yapıldığı görülmektedir. ${ }^{39}$

Artan şikâyetler üzerine Vecîhî Paşa, Ankara Valiliği’nden alınmasını talep etti. Recep 1271 (Mart-Nisan 1855)'de talebi kabul edildi ${ }^{40}$ ve şikâyet konularının araștırılması ve hakikatin ortaya çıkarılması için yeni Ankara Valisi Ali Rıza Paşa görevlendirildi. ${ }^{41}$ Ali Rıza Paşa'nın ilk aşamada şu bilgileri aktardığı görülmektedir: Vecîhî Paşa'nın en yakın adamı olan ve sırlarını bilen Osman Ăga, sorguya tabi tutulduğunda; Vecîhî Paşa'nın Yozgatlı tüccar Ohannes marifetiyle buğdayı yaz mevsiminde alıp bedelini kış mevsiminde ama yaz fiyatı üzerinden ödediğini, Haremeyn aşiretinin develeriyle Bozok kazalarından Samsun iskelesine naklettirdiğini, oğlu Kemal Paşa'nın da Haremeyn aşireti yöneticileri veya tüccardan olan kimselerle birlikte çalışarak kış aylarında hayvan sahipleriyle tanesi 18-20 kuruştan toklu satın alıp 8-10 ay sonra bunları 28-30 kuruşa sattığını böylelikle yüklü miktarda kazanç elde ettiğini ifade etmiştir. ${ }^{42}$

$\mathrm{Bu}$ arada Vecîhî Paşa ile muhakeme olunmak üzere Kangrı Kaimmakamı Mehmed Efendi, Yozgat Defterdarı Rauf Bey le diğerlerinin süratle İstanbul'a gönderilmesi emredilmişti. Hatta defterdar İstanbul'dan yeni geldiğini, pek çok masraf ettiğini, borçlu olduğunu belirtince; haksız çıktığı takdirde gelenlerin masraflarının Vecîhî Paşa tarafından karşılanacağı bilgisi kendisine iletilmiştir. ${ }^{43}$ Ancak bütün bu yazışmalar sürerken Vecîhî Paşa, Erzurum Valiliği’ne

\footnotetext{
${ }^{37} B O A, \dot{I} \cdot M V L, 117 / 22$.

${ }^{38} B O A$, I.MVL, $166 / 55$.

${ }^{39}$ BOA, A.MKT.UM, 213/53.

40 Ahmed Bâdî, Age, s.1048. 17 Mayıs 1855 tarihli bir yazıda Vecîhî Paşa'dan “Ankara sabık Valisi” diye söz edilmekte ve hüsn-i hâlinden bahsedilmektedir. BOA, I. $. M V L, 164 / 52$ (29 Şaban 1271).

${ }^{41}$ BOA, A.MKT.UM, 206/62 (19 Zilkade 1271 / 3 Ağustos 1855).

${ }^{42}$ BOA, I. $. M V L, 292 / 5$ (5 Zilhicce 1271 / 19 Ağustos 1855).

${ }^{43}$ BOA, I. MVL, 296/14 (25 Rebiulevvel 1272/ 5 Aralık 1855). 26 Rebiulevvel 1268 tarihli Sadâret kurumuna ait belgede ayrıntılı şekilde anlatıldığına göre; bir kişi hakkında dava açan şahıs, davalı ile birlikte başkalarının da İstanbul'a gelmesini talep ettiği takdirde yargılama sonucunda davacı çıkarsa davalının ve diğerlerinin masraflarını karşılamak zorundadır. Bu yüzden dava açılırken senet veya kefâlet yoluyla muhtemel bir ödeme muhafaza altına alınmaktaydı. Böylelikle garez ve haset ve benzeri sebeplerle haksız yere yapılacak suçlamalardan dolayı ayrıca mağdur olmasının önüne geçilmek istendiği konuya ilişkin bir Sadâret belgesinde ifade edilmektedir. BOA, A.MKT.NZD, 48/55. 
tayin edildi ve süratle görevine başlaması emredildi. Böylelikle mahkeme sürecinin ertelenmesi zorunluluğu ortaya çıktı. ${ }^{44}$

Vecîhî Paşa daha sonra Erzurum valiliği sırasında hakkında yayılan bazı iddialar üzerine Sadâret'e yazdığı bir yazıda yukarıda bahsedilen iddialara da atıfta bulunarak aynen şöyle demekteydi: ${ }^{45}$

\begin{abstract}
Ankara Valiliği me'mûriyet-i kemterânemde ba'zı ashâb-1 ağrâzın isnâdâtı üzerine taraf-1 kemterânemden muhâkeme taleb olundu. Her ne hâl ise uzayub nihâyet ordu-yı hümâyûna müretteb zehâir ve erzâkın celb ve cem'i nezâreti inzimâmıyla Erzurum'a me'mûriyet-i âcizânem zuhûr edüb suret-i istifâ sıdk-1 ubûdiyete münâfi göründüğ̈̈nden buraya gelindi. Şimdi burada da bu vecîhle bitakım isnâdât vuku' buldu. Taraf-1 kemterânemden ise bunların hiç birisi kabul ve tecvîz olunamayacağından gayri Rabbim bilir ki hayâl ve hâtır-1 bendegâneme bile gelür şeyler olmadığından ve Ankaraca olan isnâdât Yeniil aşiretinden dolayı olub aşiret-i merkûme meclisi ve rü'esâları istimâ'-1 kemterâneme göre şu günlerde Dersa'âdet'te bulunduklarından kendilerinden tahkik buyurulub eğerçi hakîkaten sûy-1 kemterânemden kendülerinden akçe ve boğça velev ki bir hayvan hediyeleri dahî alınmış ise îfâ-yı muktezâsını niyâz eylerim.
\end{abstract}

Görüldüğü üzere şikâyetçiler bir an evvel kendi iddialarının kabulüyle haklarının geri verilmesini talep ederken, Vecîhî Paşa da muhakeme süresinin uzamasından dert yanmakta ve bir hayvan bile alınmış ise gereği yapılsın diye 1srar etmektedir. Buna karşılık Vecîhî Paşa'nın süratle Erzurum'a gönderilmesini manidar bulanların da olduğu anlaşılmaktadır. Bu husustaki en dikkat çekici ifadeler, İngiltere'nin Erzurum Konsolosluğu tarafından gönderilen yazıda yer almaktadır. İngiliz Büyükelçiliği tarafından Hariciye Nezâreti'ne iletilen 14 Nisan 1856 tarihli yazı, Vecîhî Paşa hakkında oldukça ağır suçlamaları içerdiği gibi doğrudan hükümeti de hedef almaktaydı. Yazının tercümesi aynen şöyledir: ${ }^{46}$

Mukaddema Vecîhî Paşa hazretleri Ankara Valisi iken kendüsinin muâmelât-1 mürtekibânesinden dolayı ahâlinin vuku' bulan şikâyâtı üzerine azl ve tebdîl olunmuş ve şikâyet edenlerin birtakımı Dersa'âdet'e azimetle kendülerinden bi-gayr-i hakk ahz olunmuş olan on bin kise mikdârı matlûbât da'vâsına dair Bâbıâli'ye arzuhâl vermeleriyle cânib-i Bâbıâli' den dahi paşa-yı müşârün-ileyhin zuhûr eden bir me'mûriyeti mahsûsada hidmet-i devlet-i aliyeye lâzım olduğu cihetle davâ-yı mezkûrenin me'mûriyet-i mahsûsa-i mezkûreden vuku'-u avdetine kadar te'hîr olunmak icâb ettiği beyânıyla cevâb verilmişidi. Şu hâlden anlaşıldığına nazâran paşa-yı müşârün-ileyh Ankara'da vuku' bulan me'hûzâtından bir mikdârını bazı vükelânın himâyet ve sahâbetini istihsâl etmek içün öteye berüye vermiş olduğundan zikr olunan me'mûriyet-i mahsûsa vesîle ve bahâne ittihâz olunarak mevâdd-1 müştekânın rü'yet ve tahkîkinden sarf-1 nazâr olunmuştur. Bir de Vecîhî Paşa valilik ettiği hengâmda orduya zahîre i’tâ etmek üzere bayağı tüccâr-1 mahsûs muâmelâtına dahî girişüp o sırada pek çok temettuât-1 gayr-1 meşrûaya destres olmuş ve zâten dahi zenginlik ve idhâr-1 nükûd ve kâr u kisb uğruna her şeyi fedâ eder sıfâtıyla kesb-i şöhret etmiştir.

Hükümet yazıyı tepki ile karşıladı. Vekillerin dürüstlüğ̈ne, sadakatine ve namusuna dil uzatılmasını protesto etmek maksadıyla iddiaların ispat edilmesini isteyen bir yazının kaleme alınmasına karar verildi. ${ }^{47}$ Karar doğrultusunda İngiliz Büyükelçiliği'ne tebliğ edilen yazıda özetle şu hususlara yer verilmekteydi: Erzurum Valisi Vecîhî Paşa'nın, Ankara'dan ayrılması hakkındaki suçlamalardan ötürü istifa etmesinden dolayıdır. Kendisi hakkındaki iftiraları duyduğundan, "Beraat-1 zimmetini isbati çün bizzat taleb-i muhakeme ederek da'vâcısı var ise gelip murâfaa olmak üzere davet edilmiş ve Meclis-i Vâlâ'da icrâ-yı tahkikâta teşebbüs olunmuş olduğu halde müşârün-ileyhi ithâm edecek bir da'vâ ve hâl görünmemiştir." Erzurum için dirayetli ve işgüzâr birine ihtiyaç duyulduğundan Meclis-i Vükelâ'nın ittifakı ile bu göreve tayin edilmiş, kendisi şahsen mazeret beyan etmiş ise de devletçe israr edilerek memuriyetine gönderilmiş idi. Bahse konu mektubu yazan kişi bu vesile ile devletin vekillerini hiçbir şekilde

\footnotetext{
${ }^{44}$ BOA, I.MVL, 297/2; A. MKT. UM. 231/14.

${ }^{45}$ BOA, I.MMS, 8/319 (Belge-2. 17 Muharrem 1273 / 17 Eylül 1756. Ek-1).

${ }^{46}$ BOA, I. MMS, 7/290 (Belge-2. Ek-2); HR.TO, 222/56.

${ }^{47}$ BOA, I.MMS, 7/290 (Belge-3. 4 Şevval $1272 / 8$ Haziran 1856 tarihli arz tezkeresinin içeriği ve hazırlanan müsveddenin uygun bulunduğu 5 Şevval 1272 / 9 Haziran 1856 tarihli irade ile belirtilmiştir.)
} 
kabul olunmaz surette itham etmiş, resmî bir makamdan gelmese Büyükelçilik tarafindan Bâbıâli'ye gönderilmeyeceğinden meydana gelen iftiranın ağırlı̆̆ 1 aşikârdır. Devletin vekilleri sadece padişaha sadakat ve istikamet ile iftihar duyduklarından böyle bir töhmetine münferit olarak ne de heyetçe kabul etmeleri ve sükûtla geçiştirmeleri mümkündür. Mektubun yazarı her kim ise meydana çıkıp iddiasını ispat etmelidir veyahut iftira attığı muhakkak sayılacaktır. Böyle durumlarda namusuna zarar vermek isteyen bir takım zatları devletin vekillerinin israrla talep etme haklarını sizin de kabul edeceğiniz umulmaktadır. ${ }^{48}$

\section{Erzurum Valiliği Surasındaki İftiralar}

Bir hayli ciddî iddiaları içermesine rağmen Vecîhî Paşa'nın Ankara Valiliği sırasında sebebiyet verdiği söylenen şikâyet konuları bir neticeye bağlanmadan Erzurum Valisi Mehmed Reşid Paşa azledilerek onun yerine tayin edildi. Bu sırada Kırım Savaşı devam etmekte, Kafkas cephesinde Ruslarla savaşmakta olan Anadolu Ordusu'nun iaşe ve ikmal işlerinin daha düzenli olmasını sağlamak için kendisinin acilen göreve başlaması emredilmişti. Vecîhî Paşa 18281829 Osmanl1-Rus Savaşı'nda Edirne'de henüz genç bir paşa iken bu işlerle uğraşmış, oldukça başarılı şeyler yapmış, mülkiye kariyerindeki yükselişi de bu sayede gerçekleşmişti. Dolayısıyla Anadolu Ordusu'nun ihtiyaçlarını gidermek üzere onun seçilmesi bir tesadüf değildi.

Vecîhî Paşa Erzurum'a geldikten kısa bir süre sonra kendisinin ve adamlarının haksız yere birtakım para ve hediye aldıklarına dair dedikodular ve şikâyetler Sadâret'e ulaşmaya başladı. Bunları duyan Paşa ilginç bir yola başvurdu. Anadolu Ordusu Müşirliği ile Erzurum Meclis-i Kebiri'ne, kaza ve liva yöneticilerine gönderdiği 17 Zilkade 1272 (20 Temmuz 1856) tarihli yazısında; çeşitli iş ve görevler için tayin edilen memurların harcırah gibi yasal ödemelerini listeleyerek bunların dışında bir şey verilip veya istenip istenmediğini sormaktaydı. Yazıda; Erzurum'a geldiğinden beri maaşından başka hiçbir kimseden bir şey almadığını, hediye olunan atları bile kabul etmediğini, Erzurum'a gelirken önceden kaza müdürleri ve sairleri taraflarından haksız alınmış olan şeylerin şer'an ve kanunen muhakemesinin yapılarak hak sahiplerine geri verildiğini, amacının bütün halkın zulüm ve gereksiz masraflardan korunması olduğunu, böyle şeyler hariçten daha iyi duyulacağından, bilmediği bir şeyin duyulması veya bilinmesi halinde derhal kendisine haber verilmesini istedi. ${ }^{49}$

Bu yazı Erzurum'daki konsolosluklara da gönderilmişti. Ancak yapılan davranış hükümet tarafından yakışıksız olarak tanımlanarak tepkiyle karşılandı. Vecîhî Paşa esasında Edirne'deki, Bosna ve Belgrat'taki görevleri sırasında iyi kötü diplomasiye aşina olmuştu. Buna rağmen böyle davranmasının sebebi, Ankara'daki görevi sırasında kendisine yöneltilen suçlamalar ile İngiltere'nin Erzurum Konsolosluğu'nun hakkında yazdıklarının meydana getirdiği tepki psikolojisi olsa gerektir.

Vecîhi Paşa'nın yazısına Anadolu Ordusu Müşiri, çeşitli kazaların ve livaların müdür ve meclisleri tarafindan yazı ve mazbatalar ile cevap verildi. Avusturya Konsolosu da cevap verenler arasındaydı. Genel olarak Tanzimat usulüne ve kanunlara aykırı hiç kimseye bir şey verilmediğini, kimse tarafından da kendilerinden bir şey istenmediğini ifade ettiler. ${ }^{50}$ Alt kademedeki memurların ikbal endişesi ile böyle bir yazıya olumlu cevap verdikleri akla gelse bile Avusturya Konsolosu'nun böyle bir endişesi olmadığından yazdıklarının gerçeği yansıttığ 1 düşünülebilir. Hele de Anadolu Ordusu Müşiri İsmail Hakkı Paşa'nın, kendisiyle eşit statüde olan bir valiye şirin görünmek gibi derdi olmasa gerektir. O, yazısında kanunlara aykırı

${ }^{48}$ BOA, I..$M M S$., 7/290 (Belge-1).

${ }^{49}$ BOA, I. $. M M S, 8 / 319$ (Belge-3).

${ }^{50}$ BOA, I. $. M M S, 8 / 319$ (Belge-6, 7, 8, 9, 10, 11).

$$
\text { (1) }
$$


herhangi bir uygulamaya şahit olmadığını, bu tür sözler duymadığını, mülkî işleri en iyi şekilde bilen k1demli vezirlerden biri olarak zaten kendisinin adaletli idaresine herkesin şahitlik edeceğini, dolayısıyla emri altındaki görevlilerin de buna uygun davranacağının aşikâr olduğunu ve herhangi bir şey duyarsa ileteceğini ifade etmiştir. ${ }^{51}$

$\mathrm{Bu}$ süreçte Erzurum Meclis-i Kebiri'nin tutumu ilginçtir. Önce 20 Temmuz 1856 tarihli bir mazbata hazırlanarak Vecîhî Paşa'ya gönderilmiş olup içeriğinde, kesinlikle kanunlara aykırı bir uygulamanın olmadığı, bütün ahalinin idareden hoşnut ve razı olduğu, her şeyin yolunda gittiği ifade edilmiştir. ${ }^{52}$ Fakat bundan on beş gün sonra hazırlanan ve doğrudan Sadâret makamına gönderilen diğer bir mazbatada ise Vali hakkında çok ağır ifadeler kullanılmaktadır. Mazbatada; onun gelişinden beri ahalinin işlerine bakmayıp insanları birbirine düşürdüğü, tahkik ve tetkik etmeksizin iki de birde kazaların müdürlerini değiştirdiği, Meclisçe görülen konularla ilgili olarak şer'an ve kanunen yetkili olan reise ve hâkime güvenmeyip ekseriyetle bizzat karar verip Meclis-i Kebir'in hiçbir haysiyet ve itibarının kalmadığı, esnaftan çeşitli adlar altından aidat alındığ müsaade olunmasıyla harp zamanında bile erzak ve mal bakımından ahali zaruret çekmemişken şimdi darlık çektiği, buyruldu harcı alınması fermanla yasaklanmış iken buna uyulmadığı, kaimmakam ve müdürlerden mübaşiriye hizmeti adı altında para alındığı, kısacası eyalet işlerinin yüzüstü bırakıldığı ileri sürülmüştür. Meclis-i Kebir azaları, valinin resmi yazısının konsoloslara da gönderilmesinden dolayı hakikatin beyan edilmesine mecburiyet oluştuğunu, artık bundan sonra Vecîhî Paşa ile meclisin ve ahalinin uyumunun mümkün olamayacağını, ileride ahalinin mağdur olmaması için mahremane Sadâret makamına durumun arz edildiğini ifade etmekteydiler. ${ }^{53}$

Erzurum Meclis-i Kebiri'nin aleyhinde bir mazbata hazırlayıp İstanbul'a gönderdiğinden habersiz olan Vecîhî Paşa, Sadâret makamına sunduğu 17 Muharrem 1273 (17 Eylül 1856) tarihli yazısında yaptığı çalışmaları aktararak bir usulsüzlük olup olmadığına dair verilen cevapları özetledikten sonra hakkındaki rivayetlerin açık bir yalan olduğunu belirtmiştir. Görevi süresince Tanzimat'tan müstesna tutulan yerlerde bile akran ve emsalinden daha hafif suretle muamele yaptığını, verginin hafifletilmesi uygulamasından önce yasak olmayan hayvan hediyesini bile kabul etmediğinin aşikâr olduğunu belirtmiştir. ${ }^{54}$ Hakkındaki suçlamaların bazı garez sahiplerinin, Rum olan tercüman aracılığıyla İngiltere konsolosunun aldatılmasından kaynaklandığını düşündüğünü dile getirerek şöyle devam etmektedir: ${ }^{55}$

\footnotetext{
Bunlar da taraf-1 âcizâneme töhmet olacak ve irtikâba haml kılınacak şeyler ise febihâ, olmadığı takdîrce bunlardan mâ'adâ gerek taraf-1 âcizânemden ve gerek dâire-i nâçizânem taraflarından bir şey alınmış ise, öyle işidilmiş idi gibi lakırdı ile olmayub madde ve mahaller beyânıyla defteri matlûb buyurulub hakikaten öyle bir şey var ise ... mugâyir-i rızâ hareketi kabul ve tecvîz eylediğim için akrân ve emsâlime ibret olmak üzere icrâsına himmet (edilsin)... (Garez sahiplerinin devletin me'mûrlarını haksız yere) irtikâb ve irtişâ töhmetiyle teşhîr eylmeleri muvâfık-1 ma'dalet-i seniye ve hakkaniyet-i aliye olamayacağından gayri, mülkçe ve devletçe de muzırr şey olduğundan ve böyle sû-i zann ve şübhe altında me'mûriyette bulunmağı min-gayri haddin çâkeri-kemîneleri de kabul edemeyeceğimden ifâ-yı muktezâsını ricâ ve niyâz ederim.
}

\footnotetext{
${ }^{51}$ BOA, I.MMS, 8/319 (Belge-4. 19 Zilkade 1272 / 22 Temmuz 1856).

${ }^{52}$ BOA, I. $. M M S, 8 / 319$ (Belge-6. 17 Zilkade 1272 / 20 Temmuz 1856. Mazbatada toplam on alt katilımcidan on dördü bulunmakta, ikisinin ise görevde olduklarından dolayı toplantıya katılamadıkları görülmektedir.)

${ }^{53}$ BOA, I.MMS, 8/319 (Belge-5. 2 Zilhicce 1272 / 4 Ağustos 1856. Bu mazbatada önceki mazbatayı mühürleyen 11 kişinin mührünün yer aldığı, azalardan birinin hasta, birinin memuriyette, ikisinin de toplantıya katılmadığ görülmektedir.)

54 Vecîhî Paşa'nın sık sık hediye bile kabul etmediğini vurgulaması tesadüf değildi. Zira yasak olan rüşvet meselesini, yasak olmayan hediye ile örtbas etmek isteyenler olduğu bilinmekteydi. Hediye konusunun rüşvetle mücadele sırasında yer yer gündeme geldiğini görmekteyiz. Bkz. Yüksel Çelik, "Tanzimat Devrinde Rüşvet - Hediye İkilemi ve Bu Alandaki Yolsuzlukları Önleme Çabaları" Türk Kültürü İncelemeleri, S.XV, İstanbul 2006, s.25-64.

${ }^{55}$ BOA, I.MMS, 8/319 (Belge-2. 17 Muharrem 1273 / 17 Eylül 1856. Belgenin kopyası Ek-1'de yer almaktadır.).
} 
Vecîhî Paşa'nın gönderdiği evrak ile Erzurum Meclis-i Kebiri'nin mazbatası İstanbul'da ayrıntılı şekilde incelendi. Yapılan istişareler neticesinde Vecîhî Paşa'nın zan ve şüphe altında bulunmamak için gerekli tahkikatın yapılması yönündeki talebi uygun bulundu. Kendisini temize çıkarmak için konsoloslara resmî yazı göndermesinin hiç yakışık şey olmadığı özellikle vurguland1. Erzurum Meclisi'nin birbirine zit iki ayr1 mazbata hazırlamasından dolay1 feshedilerek yeni azaların seçilmesiyle yeniden teşkil edilmesi kararlaştırıldı. İki mazbatadan hangisinin sahih olduğunu araştırmak üzere Hariciye Mektubî kaleminden Mehmed Hûrşîd Efendi'nin özel memuriyetle Erzurum'a gönderilmesi benimsenerek, kendisine muvakkaten beş bin kuruş maaş ve on bin kuruş harcırah tayin edildi. Erzurum Meclis-i Kebiri'nin reisi olan Defterdar Hûrşî̉ Efendi ile birlikte mazbatalarda mühürleri bulunan hâkim, müftü ve nâkibüleşrâf kaimmakamı azledildi. Vecîhî Paşa'nın aleyhinde iddia edilen hususların doğru olmaması halinde sorumlular hakkında müfteri cezasının uygulanmasına karar verildi. ${ }^{56}$

Vecîhî Paşa'ya kendisinin görevden alındığı Ocak 1857'de, Meclis-i Kebir'in feshiyle usulü veçhile yeniden aza seçilmesi ve tayini için Mehmed Hûrşîd Efendi'nin görevlendirildiği, valiliğe tayin edilen Harput Valisi Arif Paşa'nın Erzurum'a gelmesine kadar şehirden ayrılmaması tebliğ edildi. Arif Paşa geldikten sonra da tahkikat bitinceye kadar Paşa'nın Erzurum'da ikamet ettirilmesi Hûrşîd Efendi'ye yazılmış ancak bu durumun gizli tutulması tembihlenmişti. ${ }^{57}$ Arif Paşa'nın 25 Şubat 1857 tarihinde Erzurum'a ulaşarak görevine başlamasına kadar Hûrşîd Efendi'nin tahkikatta pek mesafe alamadığı anlaşılmaktadır. ${ }^{58}$

$\mathrm{Bu}$ arada Vecîhî Paşa da karşı karşıya olduğu duruma yönelik kendi çapında yaptı̆̆ araştırmada hakkındaki iddiaların arkasında eski Defterdar Hûrşî̀ Efendi ile Meclis azasından Halid Efendi'nin olduğunu, konuya ilişkin olarak gönderdiği bazı belgelerin İstanbul'a ulaştırılmadığını öğrenmişti. Zira bu şahıs hakkında Bayburt mültezimlerinin kendisinden 50.000 kuruş, kayınbiraderi Emin Efendi'den 5.000 kuruş, Meclis azasından Halid Efendi'den 23.000 kuruş alacak iddiasında bulunmaları üzerine bunların geri alınmasına ilişkin birtakım işlemler yapılmıştı. Bu durumun anlatıldığı belgeler Maliye Nezâreti'ne ulaştırılmak üzere Erzurum Postahânesi'ne teslim edilmişti. Ancak İstanbul'dan gelen Mehmed Hûrşîd Efendi'den konuyu sorduğunda bu belgelerden haberdar olmadığını, İstanbul'da bulunan kapu kethüdası Mucib Bey'in yaptığı araştırmada da belgelerin akıbeti hakkında bilgi elde edemediğini öğrendi. Ortada garip bir durumun olduğu aşikârdı. Bir valinin Maliye Nezâreti'ne gönderdiği evrak kaybolmuştu. Vecîhî Paşa, büyük ölçüde artık görevinden alınmış olan Defterdar Hûrşî̉ Efendi'nin Erzurum Postahânesi Müdürü ile işbirliği yaparak, kendi ayıplarını örtbas etmek için söz konusu belgelerin gönderilmediğini ya da İstanbul'da bir şekilde kaybettirildiğini düşünmekteydi. Gerçi hemen elindeki suretlerin aynısından tekrar çıkarıp İstanbul'a göndermiş ise de, Maliye Nâzırı'ndan, böyle önemli yazışmaların zayi olmasının hem devlet işlerine zarar vereceğini hem de Postahânelere halkın güveninin kalmayacağını belirterek ihmalin nereden ve kimden kaynaklandığının araştırılması için destek istemişti. ${ }^{59}$

Vecîhî Paşa, Erzurum Valiliği sırasında irtikâp yaptığı iddiasıyla açılan soruşturma sürerken 4 Ekim 1857 tarihli irade ile Selanik Valiliği'ne tayin edildi. Buna dair hazırlanan arz tezkeresinde yazılanlar dikkat çekici olup aynen aşağıya çıkarılmıştır: ${ }^{60}$

\footnotetext{
${ }^{56}$ BOA, I.MMS, 8/319 (Belge-12. 12 safer 1273 / 12 Ekim 1856 tarihli arz tezkeresi).

${ }^{57}$ BOA, A.MKT.MHM, 102/52 (26 Rebiulevvel 1273 / 24 Kasim 1856); 266/92 (16 Cemaziyelevvel 1273 / 12 Ocak 1857); 268/82 (30 Cemaziyelevvel 1273 / 26 Ocak 1857); 269/5 (1 Cemaziyelahir 1273 / 27 Ocak 1857).

${ }^{58}$ BOA, A.MKT.UM, 272/22.

${ }^{59}$ BOA, I.MMS, 8/319 (Belge-1. 21 Cemaziyelahir 1273 / 16 Şubat 1857)

${ }^{60}$ BOA, I.MMS, 11/439 (Arz Tezkeresi 13 Safer 1274/ 3 Ekim 1857 tarihlidir. Ek-3.)
} 
Rumeli Valiliğine Selanik Valisi devletlü Abdi Paşa hazretlerinin ta’yîniyle Selanik Valiliği içün dahî hâtıra gelen zevât içinde Erzurum valisi sâbık devletlü Vecîhî Paşa hazretlerinin idâre-i umûr-1 mülkiyede olan melekesi ve zâten derkâr olan dirâyeti cihetiyle en liyâkatli görünüb müşârün-ileyhin Erzurum Valiliği esnâda hakkında vuku' bulan azviyyât üzerine Hâriciye Mektûbîsi hülefâsından Hûrşîd Efendi icrâ-y1 tahkîkât içün gönderilerek vuku' bulan tahkîkât ve ifâdât-1 mevsûkasına ve gönderdiği mazâbıt ve evrâka itibâren Meclis-i Vâlâ nazarında berâat-1 zimmeti tebeyyün etmiş olduğu beyân olunarak o ilişki dahî bertaraf olduğundan müşârün-ileyhin dahi Selanik Valisi nasb olunması münâsib gibi mutâlaa olunmuş...

Tayin tezkeresinde Vecîhî Paşa'nın suçsuz olduğu kanaati ifade edilmekle birlikte tahkikat tamamlanması ve konuya ilişkin Meclis-i Vâlâ mazbatası ancak altı ay sonra mümkün olabildi. $\mathrm{Bu}$ gecikmenin, Paşa dışındaki konu ve iddiaların da araştırılması mecburiyetinden kaynaklandığı düşünülebilir. 11 Mart 1858 tarihli Meclis kararının ayrıntıları maddeleştirilerek aşağıya çıkarılmıştır: ${ }^{61}$

1. Erzurum Valisi Vecîhi Paşa'nın hem aleyhinde hem de lehinde olmak üzere birbirine zıt mazbatalar Erzurum Meclis-i Kebiri tarafından hazırlanmıştır. Bu keyfiyet meclisin reis ve azalarının memuriyet vasıflarına aykırı göründüğünden fesh olunarak yeniden aza seçilmesini sağlamak, mazbatalardan hangisinin içeriğinin sahih olduğunu belirlemek ve valinin hakiki durumunu ortaya çıkarmak için Mehmed Hûrşîd Efedi görevlendirilmişti. Mehmed Hûrşîd Efendi tahkikatı tamamlayarak takririni ekleriyle beraber Meclis-i Vâlâ’ya sunmuştur. Bütün belgeler ayrıntılı şekilde incelenmiş ve Vecîhî Paşa hakkında ileri sürülen maddelerin aslı esası olmayan, iftira türü şeyler olduğu tespit edilmiştir.

2. Paşa'nın aleyhinde verilen mazbatayı eski azaların çoğunluğunun kerhen mühürledikleri, bunun sorumlularının Ispanakçızâde Osman Bey, eski Şehbender Halid Efendi ile meclisin reisi makamında olan Defterdar Hûrşî̉ Efendi olduğu, kendilerinin bu iftiralara ve dedikodulara sebep oldukları anlaşılmıştır.

Volume 12

Issue 2

A Tribute

to Assoc.

Prof. Dr.

İlknur

Mangir

Karagöz,

3. Mazbatada yazılanların sahih çıkmaması sebebiyle bunu mühürleyenler hakkında müfteri cezasının icra edilmesi ve müfteriye verilecek cezanın beş günden kırk beş güne kadar hapis olması ceza kanunnamesi hükmüdür. Bunlardan Halid Efendi'nin başka uygunsuz hareketleri olduğu sonradan Vali Arif Paşa tarafından ifade edildiğinden memleketi Gümüşhane'ye sürülmesi uygun bulunmuştur. $\mathrm{Bu}$ yüzden ayrıca müfteri cezasının uygulanmasına lüzum kalmamıştır.

4. Osman Bey hakkında müfteri cezası verilerek mahallinde kırk gün hapsedilmesi uygun bulunmuştur.

5. Defterdar Hûrşîd Efendi'nin Bayburt aşârı mültezimlerinden almış olduğu iddia olunan 50.000 kuruş rüşvet maddesinin mahallince muhakemesi ikmal olunmamış ve zimmetindeki parayı geri ödediği anlaşılmış ise de memurlardan bu çeşit suçlarla itham olunanların muhakemeleri mutlaka Meclis-i Vâlâ'da görülmesi kanunun 28. maddesinde yazılı olup kendisi de İstanbul'a gelmiş bulunmaktadır. Yapılan tahkikat sonucunda sözü edilen mablağın 30.000 kuruşunun Hûrşîd Efendi alacağına karşılık mahsuplaşıldığı, 20.000 kuruşun da Erzurum mal sandığına ödendiği belirlenmiş̧tir. Dolayısıyla Defterdar Hûrşîd Efendi'nin bu hususla hiçbir ilişiğinin olmadığı görülmüştür. Vecîhî Paşa aleyhindeki mazbatayı mühürlemesinden dolayı azlinin ceza için kâfi olduğuna karar verilmiştir.

6. Vecîhî Paşa tarafından azledilen Tortum Kazası Müdürü Ömer Bey ile Kiği Kazası Müdürü Süleyman Bey'in rüşvet ve zimmet suçlamasından muhakemelerin mahallince gerçekleştirilmesi, zimmetlerinde ortaya çıkacak paraların hak sahiplerine geri verilmesi için Erzurum Valisi’ne emir yazılmasına karar verilmiştir.

\footnotetext{
${ }^{61} B O A, \dot{I} . H R, 153 / 8124$. Konuya ilişkin hazırlanan ve Meclis-i Vâlâ kararı doğrultusunda işlem yapılmasını öneren 2 Şaban 1274 (18 Mart 1858) tarihli arz tezkeresinin içeriği 3 Şaban 1274 (19 Mart 1858) tarihli irade ile uygun bulunmuştur.
} 
7. İngiltere konsolos vekil ve tercümanının devletin içişlerine müdahale etmemesi hakkında sefarete gerekli tebligatın yazılması için Hariciye Nazırı'nın gereğini yapması münasip görülmüştür.

Erzurum'daki iddialarla ilgili olarak Vecîhî Paşa aklanmış ise de bir dönem malî konulardan dolayı nezaretlerle zaman zaman karşı karşıya geldiği, çeşitli yazışmalara sebebiyet verdiği görülmektedir. Hakkında ispatlanmış bir yolsuzluk ortaya çıkmamış ise de malî konularla ilgili olarak hükümet nezdinde sıkıntı yaşamaktaydı. Örneğin Maliye Nezâreti ile Deâvî Nezâreti tarafından hakkında zimmet çıkarıldığı, savunması istendiği veya zimmete konu olan meblağın ödenmesi talep ettiğinde cevap vermede ihmalkârlık yaptığı ve bu yüzden defalarca yazışmalara sebebiyet verdiği görülmektedir. Nitekim böyle bir örnek Bağdat Valiliğinden ayrılmasından sonra yaşanmıştır. Görevinden ayrılırken uhdesinde 2.230,5 kuruşun olduğu görülmektedir. Bu paranın tahsili Deâvî Nezâreti'ne havale edilmişti. Ancak kendisine gönderilen yazıya rağmen Vecihî Paşa'nın sessiz kalması üzerine Sadâret makamı tarafından hazırlanan yeni bir yazıda; zimmetindeki paranın Deâvî Nezâreti'ne ödenmesi daha önce bildirilmiş ise de henüz cevap verilmediği, söz konusu meblağın teslim edilmesi veya söyleyecek bir şey var ise bir vekilinin yollanmasını rica etmişti. ${ }^{62}$

Dönemin şartları gereğince bu tür üst düzey yöneticilere sonradan alacak veya borç çıkarılması doğal bir durumdu. Valiler başka yere tayin edildiklerinde veya azlolunduklarında maaşlarına mahsuben avans alabildikleri gibi hiç bir şey alamadan ayrıldıkları, sonradan yapılan muhasebeleştirme işlemleri neticesinde alacak - verecek hususunun netleştirildiği şeklinde bir uygulama mevcuttu. ${ }^{63}$ Bununla birlikte Vecîhî Paşa'nın böyle küçük miktardaki bir zimmet işini hemen çözmeyip yazışmalara sebebiyet vermesi anlaşılır gibi görünmemektedir. Hâlbuki yaptı̆̆ 1 yazışmalar, konulara olan hâkimiyeti, her şeyi ayrıntılı biçimde anlatmaya itina göstermesi hiç de ihmalkâr bir yönetici olduğu kanaatini uyandırmamaktadır.

\section{Selanik'teki İngiliz Konsolosu'nun İthamları}

Vecîhî Paşa'nın aleyhinde yapılan şikâyet ve iddialara rağmen $O$, hâlâ Babıâli'nin güvendiği bürokratlar arasında yer almaktaydı. Selanik gibi önemli bir yerin valiliğine tayin edilmiş olması da bunu göstermektedir. Ancak hakkındaki iddialar ile soruşturmaların, Vecîhî Paşa'nın yöneticilik anlayışına olumsuz yönde etki etmiş olmalıdır. Önceki yıllarda görülen atak, hızlı çözümler üreten, otoriter yöneticilik özelliklerinin gittikçe aşınmasında böyle olayların etkisi olduğu söylenebilir. Öte yandan özellikle İngiltere'nin konsoloslarının, her nedense Paşa'ya karşı olumsuz tavır içerisinde oldukları gözlemlenmektedir. Nitekim O'nun Selanik Valiliğine ikinci defa tayin edilmesinden kısa bir süre sonra Selanik Konsolosu Mösyö Falort tarafından 23 Haziran 1858 tarihli olarak Büyükelçiliğe, oradan da Osmanlı Hariciye Nezâreti'ne iletilen yazıda şu iddialar dile getirilmiştir: ${ }^{64}$ Bir müddetten beri Dobota adlı haydut ile adamlarının eşkıyalıkları yüzünden bölge ahalisinin can ve mal emniyeti kalmamış, mahalli hükümet cebrî tedbirlerle sonuç elde edemeyeceğini düşünerek rahat durmak ve adamlarını dağıtmak şartıyla

${ }^{62}$ BOA, A.MKT.DV, 112/6 (Yazıda tarih yok. Arkasında 5 Zilhicce 1273 / 27 Temmuz 1857 tarihi yazıll. Deâvî Nezareti'nin yazısının da 23 Zilkade 1273 /15 Temmuz 1857 tarihli olduğu anlaşılmaktadır.)

${ }^{63}$ Valilerin bu tür alacaklarının tahsili için sancaklara veya vilayetlere gönderilen fermanlar şer'iye sicillerine kaydedilmekteydi. Meselâ Behram Paşa ile halefi Yusuf Paşa'nın Saruhan Sancağında kalan bakayalarının tahsil edilmesine dair bir ferman Manisa Şer'iyye Sicili’nde yer almaktadır. Kürşat Çelik, "256 Numaralı 1236-1237 H. (1820-1822 M.) Tarihli Manisa Şer“iyye Sicilinin Tanıtımı ve Fihristi”, Firat Üniversitesi Sosyal Bilimler Dergisi, C.24, S.1, Elazı̆̆ 2014, s.264. Benzer şekilde Adana Valisi İbrahim Hilmi Paşa'nın zimmet ve bakayasının tahsil edilmesine dair bir ferman da Tarsus Şer’iye Sicilinde kayıtlıdır. Arzu Şahin, "1824-1828 (H.1240-1244) Tarihli Tarsus Şer'iyye Sicilinin Tanıtımı ve Fihristi”, Turkish Studies, C. 9, S. 4, Ankara Bahar 2014, s.1070.

${ }^{64}$ BOA, HR.TO, 230/73. Yazının arkasında 8 Zilhicce 1274/ 20 Temmuz 1858'de tebellüğ edildiği, aynı tarihte Meclis-i Vâlâ Reisi'ne takdim kılındığı yazılıdır.

$$
\text { . }
$$


bunu affetmiş ise de itibar etmemiş ve suçlarına devam ettirmektedir. Bundan birkaç gün önce Yahudi bir tüccar Selanik'ten on-on iki saat mesafedeki Lanfaza adlı mahalde öldürülmüştür. Mahalli memurlar konu hakkında bilgileri olmadığını iddia etmişlerdir. Bu eşkıyanın cezadan kurtulması zaptiye askerinin yetersizliğinden değil, yöneticilerin sahiplenmemesinden kaynaklanmıştır. Selanik Valisi iyi bir zat olmakla birlikte ziyadesiyle gevşek ve aklî metanetten mahrum olduğundan, diğer görevliler de ihmalkâr davranmaktadırlar. Dolayısıyla işleri umursamayan iyi bir adamdan ise yerine genç ve dirayetli birisinin tayin edilmesi halinde devlete daha büyük hizmet olacaktır. Bu bakımdan Tırhala Kaimmakamı Hasan Paşa'nın bu memuriyete en layık Osmanlı memuru olduğu düşünülmektedir.

Özetlenerek verilen Konsolosluk yazısında Vecîhî Paşa'nın eleştirilmesi, değiştirilmesinin talep edilmesi, hatta yerine kimin geçeceğinin dahi ile getirilmesi, yabancı devlet temsilcilerinin içişlerine karıştırılmaması konusundaki duyarlılığa aykırı bir durum oluşturmaktaydı. Hükümet de bu konuda duyarlı olduğunu diplomatik üslupla ifade etmeye çalışmaktaydı. Ancak yine de özellikle İngilizlerin taleplerine karşı bir şeyler yapıldığını görmekteyiz. Nitekim bu yazıdan birkaç ay sonra, Sadrazam tarafından Selanik Valiliği için en liyakatli kişi olarak tanımlanıp bu göreve getirilen Vecîhî Paşa, haklı ya da haksız araştırması yapılmadan görevinden azledildi. Yerine önce Bosna Valisi Kâni Paşa'nın ataması ile ilgili ferman çıktı ise de göreve başlamadan karar değiştirilerek Üsküp Mutasarrıfı Âkif Paşa tayin edildi ve İngiliz konsolosunun talebi kısmen yerine getirilmiş oldu. ${ }^{65}$

Böylelikle XIX. yüzyılda sıklıkla rastlanan, başta İngiliz temsilcileri olmak üzere büyük devletlerin elçi ve konsoloslarının Osmanlı Devleti'nin içişlerine müdahalelerinin yeni bir örneği ile karşılaşılmış oldu. ${ }^{66}$ Hükümet yer yer bu konuda büyükelçilikleri diplomatik üslupla uyarmaktaydı. Ancak dönemin şartları dolayısıyla çeşitli devlet temsilcilerinin ülkenin içişlerine müdahalelerde bir hayli hoyratça davranmaya devam ettikleri görülmektedir. ${ }^{67}$

Volume 12

Issue 2

A Tribute

to Assoc.

Prof. Dr.

İlknur

Mangir

Karagöz,

April

2020

\section{Sonuç}

Mehmed Vecîhî Paşa üç padişah döneminde valilik yapmış, hakkında önemli sayıda şikâyetlerin bulunduğu devlet adamlarından biridir. Kırk yıllık zaman dilimini kapsayan bu görevlerinde, Selanik’teki İngiliz konsolosunun iddiaları sayılmazsa, yöneticilik vasıflarıyla ilgili değil de daha ziyade haksız kazanç, rüşvet alma gibi suçlamaların olduğu görülmektedir. En ciddî suçlamaları yapanlar arasında muhtelif aşiret temsilcilerinin ön planda olduğu söylenebilir. Yapılan işlemlerden anlaşıldığı kadarıyla hükümet bu iddiaları çok ciddiye

${ }^{65}$ BOA, A.DVN., 134/87 (11 Safer 1275 / 20 Eylül 1858); 135/75 (20 Rebiulevvel 1275 / 28 Ekim 1858); A.MKT.NZD, 267/61 (24 Rebiulevvel 1275 / 1 Kasim 1858); I.DH, 420/27798 (16 Cemaziyelevvel 1275 / 22 Aralık 1858).

${ }^{66}$ Selanik Defterdarı Muhyiddin Bey de, İngiliz Konsolosunun aleyhindeki yazısı üzerine derhal azledilmiş idi. BOA, HR.MKT, 211/84 (1 Rebiulevvel 1274 / 20 Ekim 1857); 212/42 (4 Rebiulevvel 1274 / 23 Ekim 1857).

${ }^{67}$ Meselâ Âli Paşa, Paris Kongresi'nde buna dair şikâyetlerini dile getirmişti. Ahmed Cevdet Paşa, Ma'rûzât, Haz. Yusuf Halaçoğlu, Çağrı Yayınları, İstanbul 1980, s.195; Ali Fuat Türkgeldi, Mesâil-i Mühimme-i Siyasiyye, C.I, Yay.: B. S. Baykal, Türk Tarih Kurumu Yayınları, Ankara 1960, s.115, 383. Yabanc1 ülke temsilcileri, hatta yerli ahaliden istihdam ettikleri tercümanlar, Osmanlı vatandaşı gayrimüslimler ile ilgili egemenlik haklarını ihlal edici davranışlar ve müdahaleler sergiledikleri gibi Müslüman unsurları da kullanmak ve kışkırtmak için girişimlerde bulunmaktan çekinmemekteydiler. Bazı örnekler için bkz. Albert Hourani, "Ottoman Reform and the Politics of Notables", Beginnings of Modernization in theMiddle East, The Nineteenth Century, Ed.: William R. Polkand Richard L. Chambers, University of Chicago Press, Chicago and London 1968, s.41-68; Salahi R. Sonyel, "The Protégé System in the Ottoman Empire and Its Abuses", Belleten, C.XXX, S.214, Ankara 1991, s.675-686; Kemal Çiçek, "Osmanlı Devleti'nde Yabancı Konsolosluk Tercümanları", Tarih ve Toplum, S.146, İstanbul 1996, s.17-23. $\mathrm{Bu}$ müdahalelerin ilginç örneklerden biri Ceride-i Havadis gazetesinin sahibi Churchill ile ilgili olanıydı. Ayrıntılar için bkz. Orhan Koloğlu, Miyop Çörçil Olayı, Yorum Yayınları, Ankara 1986; Nedim İpek, "Churchill Vak'ası”, Ondokuzmayls Üniversitesi Ë̆itim Fakültesi Dergisi, S.8, Samsun 1993, s.105-146. 
almamıştır. Çünkü çok büyük sıkıntı kaynağı olan aşiret iskânında oldukça başarılı işler yapmış; bu ve benzeri çalışmaları dolayısıyla defalarca takdir edilerek, oğullarına mevki ve makam verilerek, nişan takılarak ödüllendirilmişti. Dolayısıyla yapılan şikâyetler garez, nefret, intikam duygusu, çıkar elde etme gibi gerekçelere bağlanmış olmalıdır.

Bâbâli'nin her zaman önem verdiği paşalardan biri olan Vecîhî Paşa da, bir itham veya töhmet olduğunda büyük bir özgüvenle hakkında derhal tahkikat yapılmasını, görevinden alınmasını, suçunun sabit olması durumunda ibret olması için en ağır şekilde cezalandırılmasını istemekteydi. Bunun İstanbul'daki yöneticiler üzerinde olumlu etki yapmış olduğu tahmin edilebilir. Nitekim bir görevden azledildikten kısa bir süre sonra yeniden, hatta bazen çok daha önemli bir göreve tayin edildiği görülmektedir.

\section{KAYNAKÇA}

\section{Devlet Arşivleri Başkanlığı Osmanlı Arşivi (BOA)}

Cevdet - Askeri (C.AS), 1210/54228.

Cevdet - Dâhiliye (C.DH), 219/10902, 296/14752.

Cevdet - Maliye (C.ML), 34/1554.

Divân-ı Hümâyûn Kalemi (A.DVN), 15/39, 112/62, 46/60, 58/82, 134/87, 135/75.

Hatt-ı Hümâyûn (HH), 660/32233, 1328/51808, 306/18057, 1042/43108, 308/18229, $1042 / 43110,1052 / 43307$.

Hariciye Mektûbî (HR.MKT), 211/84, 212/42.

Hariciye Tercüme Odasl (HR.TO), 222/56, 230/73.

Irade - Dâhiliye (I.DH), 214/12530, 149/7738, 154/7995, 179/9803, 225/13448, 132/3525, 256/15805, 258/15909, 47/2317, 66/3251,420/27798,

Irade - Hariciye (I.HR), 153/8124.

Irade-Meclis-i Mahsûs (İ.MMS), 7/290, 8/319.

Irade - Meclis-i Vâlâ (İ.MVL), 3/57, 116/14, 117/22, 164/52, 164/52, 51/33, 52/32, 166/55, 244/46, 292/5, 296/14, 297/2, 302/25.

Mektûbî Kalemi (A.MKT), 37/8, 92/30, 232/23.

Mektûbî Kalemi - Deâvî (A.MKT.DV), 104/81, 112/6, 132/42.

Mektûbî Kalemi - Meclis-i Vâlâ (A.MKT.MVL), 77/55.

Mektûbî Kalemi - Nezâret ve Devâir (A.MKT.NZD), 155/58, 267/61, 48/55, 55/33, 8/43.

Mektûbî Kalemi - Umum Vilâyet (A.MKT.UM), 15/86, 206/62, 104/90, 213/53, 231/14, $272 / 22$.

Mektûbî Mühimme Kalemi (A.MKT.MHM), 46/79, 1/72, 102/52; 266/92; 268/82; 269/5.

Sadâret Müteferrik Belgeler (A.M), 11/10, 16/59.

\section{Kitap ve makaleler}

Ahmed Bâdî Efendi, Riyâz-ı Belde-i Edirne,20. Yüzyıla Kadar Osmanlı Edirne'si, Haz. Niyazi Adıgüzel ve Raşit Gündoğdu, C.II/1, Trakya Üniversitesi Yayınları, İstanbul 2014.

Ahmed Cevdet Paşa, Ma'rûzât, Haz. Yusuf Halaçoğlu, Çağrı Yayınları, İstanbul 1980.

\section{History Studies}


ÇADIRCI, Musa, "II. Mahmud Döneminde Mütesellimlik Kurumu, Dil ve Tarih - Coğrafya Fakültesi Dergisi, C.XXVIII, S.3-4 (Temmuz - Aralık 1970), s.287-296.

ÇELIK, Kürşat, "256 Numaralı 1236-1237 H. (1820-1822 M.) Tarihli Manisa Şer"iyye Sicilinin Tanıtımı ve Fihristi”, Firat Üniversitesi Sosyal Bilimler Dergisi, C.XXIV, S.1, Elazı̆̆ 2014, s.255-267.

ÇELIK, Yüksel, "Tanzimat Devrinde Rüşvet - Hediye İkilemi ve Bu Alandaki Yolsuzlukları Önleme Çabaları”, Türk Kültürü İncelemeleri, S.XV, İstanbul 2006, s.25-64.

ÇIÇEK, Kemal, “Osmanlı Devleti'nde Yabancı Konsolosluk Tercümanları”, Tarih ve Toplum, S.146, İstanbul 1996, s.17-23.

GÖLEN, Zafer, “Bosna Valisi Mehmed Vecîhî Paşa'nın Muhakemesi”, Belleten, C.LXXVI, S.277, Aralık 2012, s.849-877.

GÜLSOY, Ufuk, 1828-1829 Osmanlı - Rus Savaşı'nda Rumeli'den Rusya'ya Götürülen Reâyâ, Türk Kültürünü Araştırma Enstitüsü Yayınları, İstanbul 1993.

Volume 12

Issue 2

A Tribute

to Assoc.

Prof. Dr.

İlknur

Mangir

Karagöz,

April

2020

HOURANI, Albert, "Ottoman Reform and the Politics of Notables", Beginnings of Modernization in the Middle East, The Nineteenth Century, Ed.: William R. Polkand Richard L. Chambers, University of Chicago Press, Chicago and London 1968, s.41-68.

İPEK, Nedim, “Churchill Vak'ası”, Ondokuzmayıs Üniversitesi Eğitim Fakültesi Dergisi, S.8, Samsun 1993, s.105-146.

İsmail Sadık Kemal bin Muhammed Vecîhî Paşa, Asâr-ı Kemâl, İstanbul 1867.

KOLOĞLU, Orhan, Miyop Çörçil Olayı, Yorum Yayınları, Ankara 1986.

Mehmed Süreyya, Sicill-i Osmanî, Haz. Nuri Akbayar, C.III, V, Tarih Vakfı Yurt Yayınları, İstanbul 1996.

ÖZKAYA, Yücel, "XVIII Yüzyılda Mütesellimlik Müessesesi”, Dil ve Tarih - Coğrafya Fakültesi Dergisi, C.XXVIII, S.3-4 (Temmuz - Aralık 1970), s.369-390.

SAYDAM, Abdullah, "1828-1829 Türk - Rus Savaşı ve Bir Bürokratın Doğuşu: Mehmed Vecîhî Paşa”, History Studies, C.XI, S.4, Samsun Ağustos 2019, s.1341-1361.

SAYDAM, Abdullah, “Orta Anadolu'da Aşiret İskânları (1839-1853), Prof. Dr. Bayram Kodaman'a Armăgan, ed.: M. A. Ünal, Eser Matbaas1, Samsun 1993, s.227-256.

SONYEL, Salahi R., "The Protégé System in the Ottoman Empire and Its Abuses", Belleten, C.XXX, S.214, Ankara 1991, s.675-686.

ŞAHIN, Arzu, "1824-1828 (H.1240-1244) Tarihli Tarsus Şer'iyye Sicilinin Tanıtımı ve Fihristi", Turkish Studies, C. IX, S. 4, Ankara Bahar 2014, s.1061-1084.

TÜRKGELDI, Ali Fuat, Mesâil-i Mühimme-i Siyasiyye, C.I, Yay.: B. S. Baykal, Türk Tarih Kurumu Yayınları, Ankara 1960.

UZUN, Mustafa, “Câize”, DİA, C.VII, İSAM Yayınları, İstanbul 1993, s.28-29. 


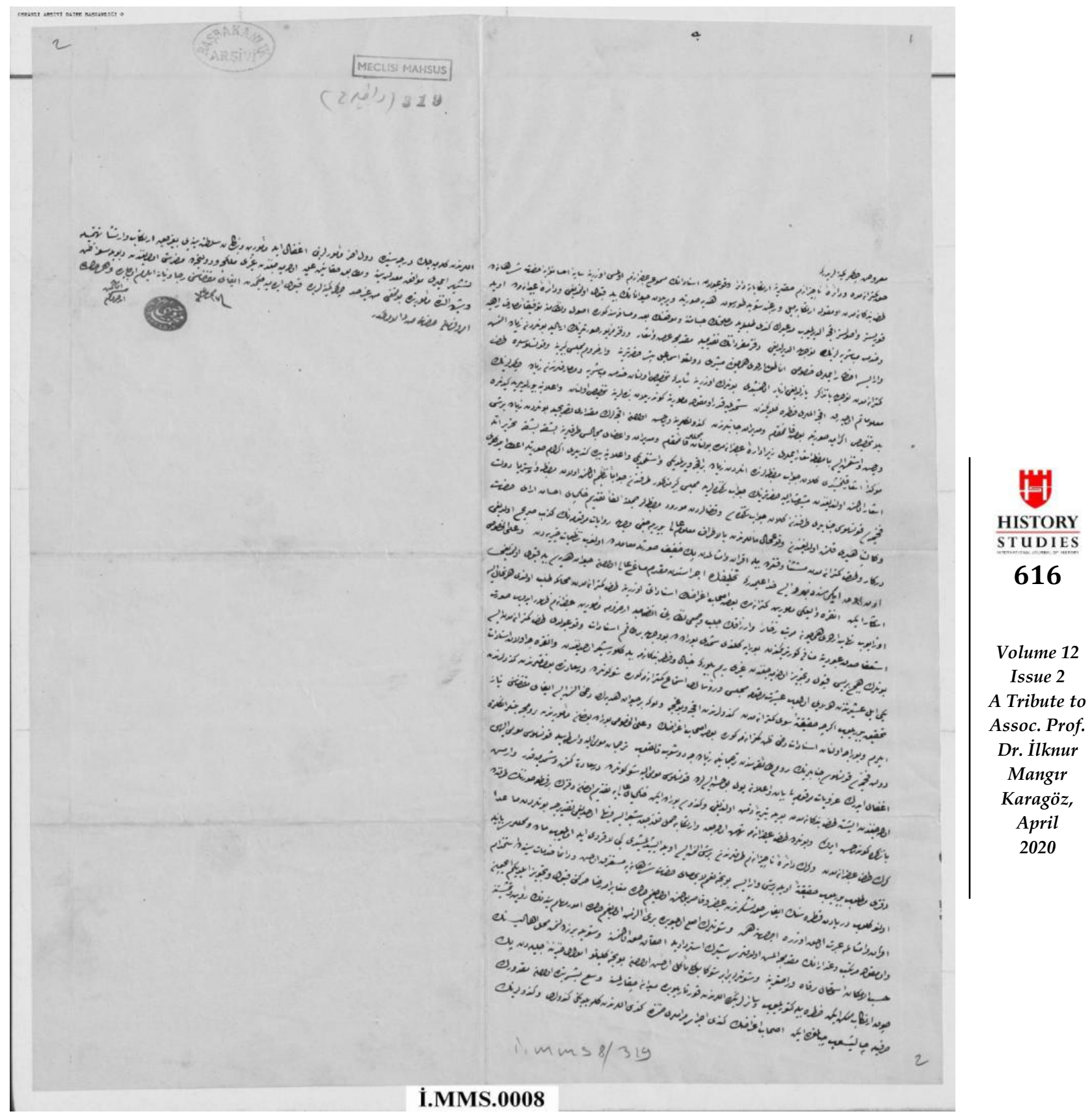

EK-1. Vecîhi Paşa tarafindan yazılan yazı 


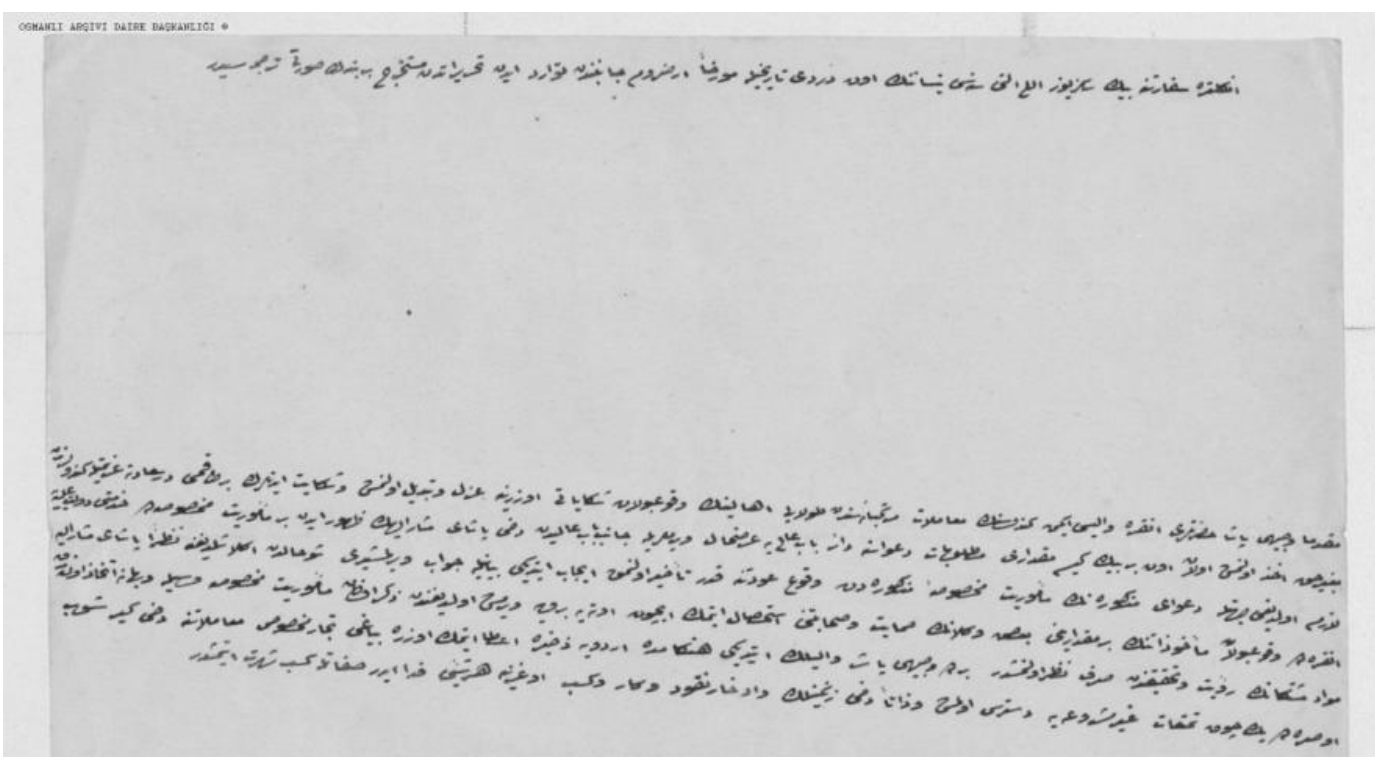

HISTORY

STUDIES

617

Volume 12

Issue 2

A Tribute

to Assoc.

Prof. Dr.

İlknur

Mangir

Karagöz,

April

2020

\section{İ.MMS.0007}

Ek-2. İngiliz Sefâretinin yazısı. 


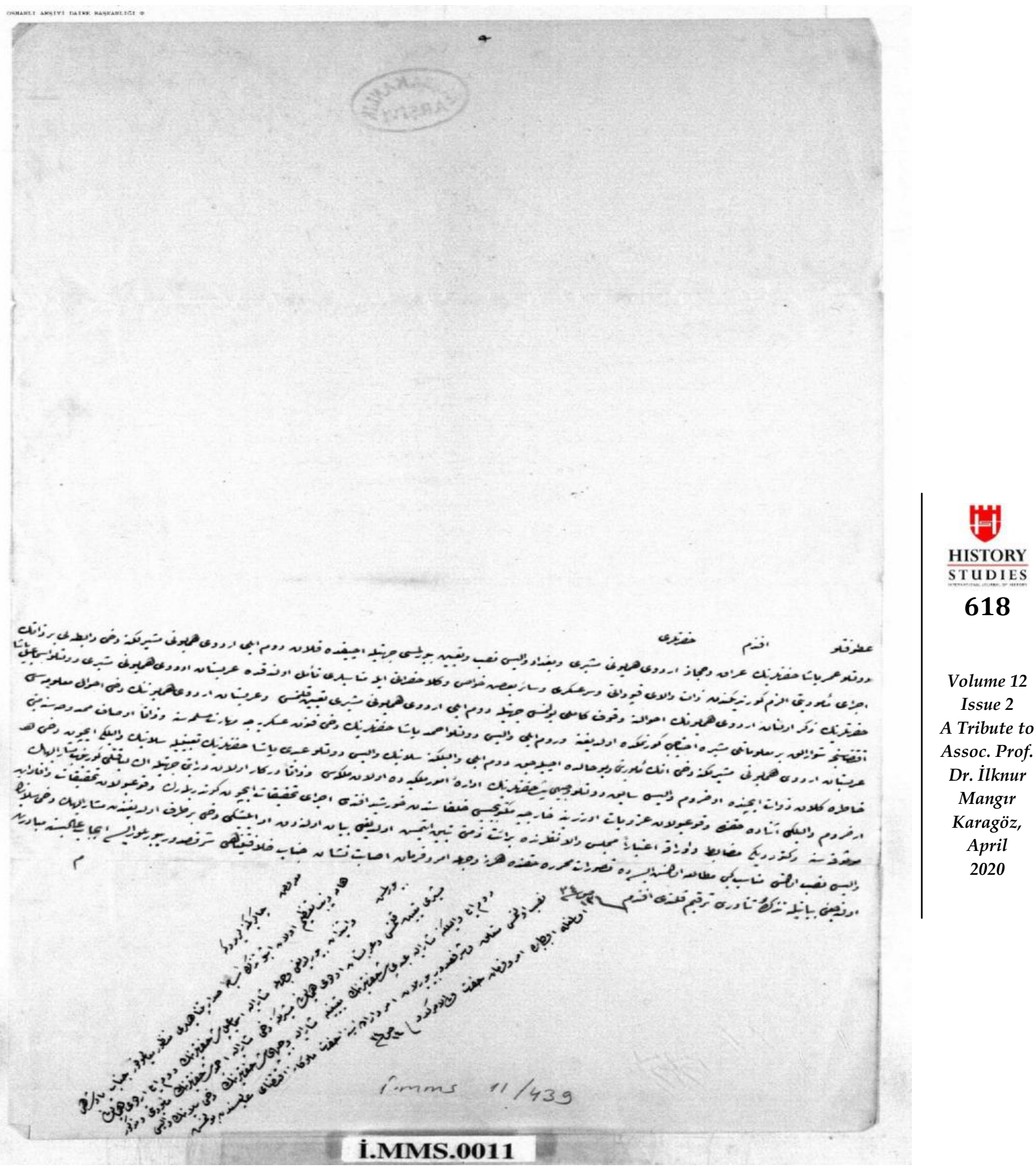

Ek-3. Vecîhî Paşa'nın Selanik Valiliği' ne tayin edildiğine dair arz tezkeresi. 